\title{
MONIKA ŻURAW
}

\author{
Uniwersytet Kardynała Stefana Wyszyńskiego
}

\section{FUNKCJE ZNAKU TOWAROWEGO W ORZECZNICTWIE EUROPEJSKIEGO TRYBUNAŁU SPRAWIEDLIWOŚCI}

\section{ZAGADNIENIA WSTĘPNE}

Prawo znaków towarowych w państwach członkowskich zostało ujednolicone „Pierwszą Dyrektywą Rady (WE) z dnia 21 grudnia 1988 r. mającą na celu zbliżenie ustawodawstw Państw Członkowskich odnoszących się do znaków towarowych" (Dz.U. L 207 19/07/1989)' (zwaną dalej „Dyrektywą”). W prawie polskim jej postanowienia implementuje Ustawa $\mathrm{z}$ dnia 30 czerwca 2000 r. Prawo własności przemysłowej (Dz.U. z 2003 Nr 119, poz. 1117 - tekst jednolity - ze zm., zwana dalej „Pwp”). Choć pkt. 3 Preambuły Dyrektywy stanowi, iż zbliżeniu podlegają tylko te aspekty prawa znaków towarowych, które mają najbardziej bezpośredni wpływ na funkcjonowanie wspólnego rynku, de facto reguluje ona niemal wszystkie najważniejsze zagadnienia. Drugim źródłem wspólnotowego prawa znaków towarowych jest Rozporządzenie Rady (WE) Nr 40/94 z dnia 20 grudnia 1993 r. w sprawie wspólnotowego znaku towarowego (Dz.U. L 11

1 Tłumaczenie (nieoficjalne) tekstu polskiego znajduje się pod adresem http://europa.eu.int/smartapi/cgi/sga_doc?smartapi!celexapi!prod!CELEXnumdoc $\& \lg =$ PL\&numdoc $=31989$ L0104\& model $=$ guichett. 
14/01/1994)² (zwane dalej „Rozporządzeniem”) regulujące tzw. prawo do znaku wspólnotowego. W kwestiach mających znaczenie dla niniejszego opracowania Rozporządzenie całkowicie powiela rozwiązania przyjęte w Dyrektywie.

Jedną z kompetencji Europejskiego Trybunału Sprawiedliwości jest udzielanie odpowiedzi na pytania prawne ${ }^{3}$ odnoszące się do wykładni prawa wspólnotowego (art. 234 Traktatu Ustanawiającego Wspólnotę Europejską, zwanego dalej „TWE”). ETS rozpatruje także, w ograniczonym zakresie, odwołania od wyroków Sądu I Instancji (art. 225 TWE); w odniesieniu do prawa znaków towarowych orzeka w sprawie skarg na decyzje Urzędu Harmonizacji Rynku Wewnętrznego wydawanych na podstawie Rozporządzenia ${ }^{4}$. W ramach tych kompetencji ETS kształtuje wykładnię przepisów wspólnotowego prawa znaków towarowych. Moc wiążąca erga omnes wyroków ETS mających za przedmiot wykładnię przepisów prawa wspólnotowego jest kwestią dyskusyjną. Niemniej jednak przyjmuje się, iż sądy państw członkowskich powinny stosować interpretację przepisów przyjętą $w$ orzeczeniach wydanych przez ETS w postępowaniu dotyczącym pytań prawnychs'. Orzekanie w sposób odmienny przede wszystkim podważałoby cel postępowania $z$ art. 234 TWE, którym jest zapewnienie jednolitej wykładni i stosowania prawa wspólnotowego ${ }^{\circ}$.

Orzecznictwo ETS powinno mieć szczególne znaczenie dla polskich sądów orzekających w sprawach znaków towarowych ze względu na stosunkową nowość tematyki, a w związku z tym niewielki dorobek orzecznictwa. Powszechne odwoływanic się do

: Tłumaczenie (oficjalne) tekstu polskiego znajduje się pod adresem http://europa.eu.int/smartapi/cgi/sga_doc?smartapi!celexapi!prod!CELEXnumdoc\&num$\mathrm{doc}=31994 \mathrm{R} 0040 \&$ model $=$ guichett $\& \mathrm{lg}=\mathrm{pl}$.

'Terminologia przyjęta za A. WróBlem, Stosowanic prawa Unii Europejskicj przez squdy, Zakamycze 2005, s. 770.

+ Por. art. 63 Rozporządzenia i pkt. 6 Preambuly Rozporządzenia.

'A. Wróbel, op. cit., s. 811-812.

"A. Wróbel, op. cit., s. $811 \mathrm{i} \mathrm{n.}$ 
orzeczeń ETS ułatwi wypracowanie jednolitych oraz zgodnych z prawem wspólnotowym koncepcji w prawie znaków towarowych.

Przepisy Dyrektywy nie nazywają funkcji pełnionych przez znak towarowy. Jedynie pkt. 10 Preambuły mówiący o zakresie ochrony praw do znaku stanowi, iż ,[...] ochrona udzielona zarejestrowanemu znakowi towarowemu, [która] w szczególności ma mu zapewnić funkcję wskazywania pochodzenia [...]". Zarówno w doktrynie jak i orzecznictwie zgodnie przyjmuje się, iż prawnie relewantne są: funkcja odróżniająca, jakościowa (zwana też gwarancyjną) oraz reklamowa ${ }^{8}$. Funkcja odróżniająca wyraża się w odróżnianiu towarów

' Pkt. 10 Preambuły Dyrektywy: „ochrona udzielana zarejestrowanemu znakowi towarowemu, która w szczególności ma mu zapewnić funkcję wskazania pochodzenia, jest całkowita w przypadku identyczności między znakiem i oznaczeniem oraz towarami lub usługami; ochrona ma zastosowanie również do przypadków podobieństwa między znakiem a oznaczeniem oraz towarami lub usługami; pojęcic podobieństwa należy interpretować w odniesieniu do prawdonodobieństwa wprowadzenia w błąd; prawdopodobieństwo wprowadzenia w bląd, którego ocena zależy od wielu czynników, w szczególności rozpoznawalności znaku towarowego na rynku, mogącego powstać skojarzenia ze znakiem używanym lub zarejestrowanym, stopnia podobieństwa między znakiem towarowym i oznaczeniem, między określonymi towarami lub usługami, stanowi szczególny warunek dla takiej ochrony; sposoby ustalania prawdopodobieństwa wprowadzenia w błąd, w szczególności ciężar dowodu, są regulowane przez krajowe zasady proceduralne, których dyrektywa nie narusza.

${ }^{8} \mathrm{~W}$ polskiej doktrynie na temat funkcji znaku towarowego m.in. J. KocZANOwSKI, Funkcje i ochrona prawa znaków towarowych, «ZNUJ PWiOWI», 1976 z. 8, s. 49-63; R. SKUBISZ, Prawo z rejestracji znaku towarowego i jego ochrona, Lublin 1988, s. 19-26; TENŻE, Funkcje znaku towarowego, Ksiega pamiątkowa z okazji 80-lecia rzecznictwa patentowego w Polsce, Warszawa 2001, s. 163-182; K. SzCZEPANOWSKA-KozłowsKA, Wyczerpanie praw wtasności przemystowej. Patent $i$ prawo ochronne na znak towarowy, Warszawa 2003, s. 66 i n.; w literaturze zagranicznej m.in.: W. R. CoRnish, Intellectual Property: Patent, Copyright, Trade Marks and Allied Rights ${ }^{4}$, Sweet \& Maxwell 1999, s. 612-616, J. ThOMAS MCCARTHY, McCarthy on Trademarks and Unfair Competition, ${ }^{4}$, West Group Rel. 2001, s. 3.3 i n., P. MATHELY, Le droit francais des signes distinctifs, «Journal des Notaires at des Avocats» 2001, s. 11-15; F. K. BEIER, Territoriality of Trademark Law and International Trade, «IIC» $1979 \mathrm{nr}$ 1, s. 61-65; LoRd MACKENZIE StUART, The Function of Trade Marks and the Free Movement of Goods in the European Economic Community, «IIC» $1976 \mathrm{nr} 1$, s. 27 i n. 
lub usług jednego przedsiębiorstwa od tych pochodzących $\mathrm{z}$ innych przedsiębiorstw9. Za funkcję jakościową można uznać zdolność znaku towarowego gwarantowania określonych cech towaru opatrzonego znakiem, w szczególności jego jakości. Funkcję reklamową definiuje się jako zdolność do wywoływania u odbiorców pozytywnych skojarzeń, a w konsekwencji zachęcanie ich do zakupu danego towaru również tylko ze względu na fakt sygnowania ich określonym oznaczeniem. Funkcją pierwotną znaku towarowego jest odróżnianie towarów i usług pochodzących z różnych przedsiębiorstw. Pozostałym dwom funkcjom przyznaje się pochodny charakter, jako że znak towarowy może nieść określony komunikat dopiero, gdy jest kojarzony przez odbiorców z towarem i przedsiębiorstwem, z którego pochodzi.

Istotą prawa znaków towarowych jest ochrona funkcji odróżniającej, która wyraża się przede wszystkim w ochronie przed wprowadzeniem w bląd klienta co do pochodzenia towaru, a w przypadku użycia oznaczenia identycznego jest ochroną absolutną ${ }^{10}$. Przesłanki ochrony prawa do znaku towarowego wyrażone są w art. 5 Pkt. 1 Dyrektywy".

${ }^{9}$ Funkcja odróżniająca zwana jest też funkcją pochodzenia. Większość polskich autorów stosuje te terminy wymiennie, m.in. R. SKUBISZ, Funkcje znaku towarowego, [w:] Księga Pamiątkowa z okazji 80-lecia rzecznictwa patentowego w Polsce, Warszawa 2001, s. 167; I. WISZNIEWSKA, Znaki towarowe w prawie wtasności przemystowej, «PPH» $2001 \mathrm{nr}$ 10, s. 6; U. PromińSKa, Prawo wlasności przemystowej. Przepisy $i$ omówienie, Warszawa 2003, s. 189. Terminy te nie są jednak ekwiwalentne. Funkcja wskazywania na pochodzenie towaru z określonego przedsiębiorstwa charakteryzowała wcześniejsze prawodawstwa, w prawie polskim patrz art. 174 Rozporządzenia Prezydenta Rzeczypospolitej z 22 marca 1928 r. o ochronie wynalazków, wzorów i znaków towarowych (Dz.U. z 1928 r. Nr 39, poz. 384 ze zm.). Wspólczesne ustawodawstwa akcentują zdolność odróżniania towarów pochodzących $\mathrm{z}$ różnych przedsiębiorstw, a nie związek znaku towarowego z określonym źródłem pochodzenia.

"Co podkreśla pkt. 10 Preambuły Dyrektywy.

"Art. 5 pkt. 1 brzmi: 1. Zarejestrowany znak towarowy przyznaje właścicielowi wyłączne prawa do tego znaku. Właściciel jest uprawniony do zakazania wszelkim stronom trzecim, które nie posiadają jego zgody, używania w obrocie handlowym: a) oznaczenia identycznego ze znakiem towarowym dla towarów lub usług iden- 
Funkcja odróżniająca chroniona jest w sposób najpełniejszy oraz niezależnie od pozostałych funkcji znaku towarowego. Niewątpliwe jest również, że ochrona samodzielna przysługuje także funkcji reklamowej w przypadku znaku renomowanego, o ile ustawodawstwo krajowe taką ochronę przewiduje - art. 5 (2) Dyrektywy ${ }^{12}$. O innych przypadkach ochrony poszczególnych funkcji znaku towarowego można wnioskować $\mathrm{z}$ wielu przepisów, których rolą pierwszoplanową jest regulacja zagadnień niezwiązanych bezpośrednio $z$ naruszeniem praw do $\mathrm{znaku}^{13}$.

Wobec braku bezpośrednich i jednoznacznych rozstrzygnięć w tekście Dyrektywy niemal wszystkie kwestie związane z przesłankami naruszenia prawa do znaku towarowego wymagają przeprowadzenia wykładni stosownych przepisów. Zagadnieniem kluczowym jest odpowiedź na pytanie w jakim zakresie chronione są interesy uprawnionego wyrażające się $w$ ochronie funkcji odróżniającej. Czy jest to wyłącznie ochrona przed ryzykiem wprowadzenia w błąd co do pochodzenia towarów lub usług, czy obejmuje ona również ryzyko powstania skojarzeń między oznaczeniami. Kolejnym dyskusyjnym zagadnieniem jest zakres ochrony znaku w przypadku identyczności oznaczenia użytego przez osobę trze-

tycznych z tymi, dla których znak towarowy jest zarejestrowany; b) oznaczenia, w przypadku którego z powodu jego identyczności lub podobieństwa do znaku towarowego oraz identyczności lub podobieństwa towarów lub usług, których dotyczy znak towarowy i to oznaczenie, istnieje prawdopodobieństwo wprowadzenia w błąd wśród opinii publicznej, które obejmuje prawdopodobieństwo skojarzenia oznaczenia ze znakiem towarowym.

${ }^{12}$ Art. 5 pkt. 2 Dyrektywy w brzmieniu: „Każde Państwo Członkowskie może również postanowić, że właściciel jest uprawniony do zakazania wszelkim osobom trzecim, które nie posiadają jego zgody, używania w obrocie handlowym: oznaczenia identycznego lub podobnego do znaku towarowego w odniesieniu do towarów lub usług, które nie są podobne do tych, dla których zarejestrowano znak towarowy, w przypadku gdy cieszy się on renomą w Państwie Członkowskim i w przypadku gdy używanie tego oznaczenia bez uzasadnionej przyczyny powoduje nienależną korzyść lub jest szkodliwe dla odróżniającego charakteru lub renomy tego znaku towarowego.

${ }^{13}$ Ich treść będzie powolana przy omówieniu orzeczeń, które będą ich dotyczyć. 
cią; czy chroniona jest jedynie funkcja odróżniająca, czy niezależnie także inne funkcje znaku. Odwołanie się do funkcji podlegających ochronie przepisami Dyrektywy jest często konieczne również $\mathrm{w}$ związku $\mathrm{z}$ przeprowadzeniem wykładni przepisów związanych $z$ innymi kwestiami prawa znaków towarowych, a nie tylko bezpośrednio $\mathrm{z}$ przesłankami naruszenia prawa tj. przede wszystkim ze zdolnością rejestrową i przesłankami unieważnienia znaku towarowego, ograniczeniami prawa ochronnego oraz instytucją wyczerpania praw do znaku.

Wyznaczenie granic ochrony poszczególnych funkcji znaku towarowego poza interesami uprawnionego do znaku musi uwzględniać interesy innych uczestników obrotu. W ramach prawa wspólnotowego konieczne jest także odniesienie praw przysługujących uprawnionemu do zasad wspólnego rynku, przede wszystkim swobody przepływu towarów i usług ${ }^{14}$. Właśnie w ramach tego ostatniego zagadnienia, jeszcze wiele lat przed wejściem w życie Dyrektywy, ETS po raz pierwszy zajmował się określeniem funkcji znaku towarowego. Art. 30 TWE (poprzednio art. 36) wprowadza wyjątek od zasady swobodnego przepływu towarów i usług (obecnie art. 28, $29 \mathrm{TWE})^{15} \mathrm{~m}$.in. ze względu na ochronę własności przemysłowej i handlowej ${ }^{16}$. Dyrektywa reguluje w sposób całościowy i szczegółowy zagadnienia związane $\mathrm{z}$ ochroną znaków towaro-

\footnotetext{
${ }^{14}$ Patrz pkt. 1 Preambuły Dyrektywy.

${ }^{15}$ Art. 28: Ograniczenia ilościowe w przywozie oraz wszelkie środki o skutku równoważnym są zakazane między Państwami Członkowskimi. Art. 29: Ograniczenia ilościowe w wywozie oraz wszelkie środki o skutku równoważnym są zakazanc między Państwami Członkowskimi.

1" Art. 30: Postanowienia artykulów 28 i 29 nie stanowią przeszkody w stosowaniu zakazów lub ograniczeń przywozowych, wywozowych lub tranzytowych, uzasadnionych względami moralności publicznej, porządku publicznego, bezpieczeństwa publicznego, ochrony zdrowia i życia ludzi i zwierząt lub ochrony roślin, ochrony narodowych dóbr kultury o wartości artystycznej, historycznej lub archeologiczncj, bądź ochrony własności przemysłowej i handlowej. Zakazy te i ograniczenia nie powinny jednak stanowić środka arbitralnej dyskryminacji ani ukrytych ograniczeń w handlu między Państwami Członkowskimi.
} 
wych, również w kontekście powołanych wcześniej przepisów TWE. Zatem to przepisy Dyrektywy mają charakter pierwszoplanowy. Niemniej jednak muszą być one interpretowane w świetle postanowień TWE. Z tego względu ETS przeprowadzając wykładnię Dyrektywy do tej pory korzysta z większości koncepcji przyjętych przed jej wejściem w życie.

\section{PRZEGLĄD ORZECZNICTWA}

Niniejszy przegląd orzecznictwa ma zaprezentować w ujęciu historycznym dorobek ETS dotyczący funkcji znaku towarowego. Szczegółowo zostaną omówione orzeczenia, w których wypracowano nowe koncepcje. Te, które powtarzają wcześniejsze formuły, będą jedynie przytoczone ${ }^{17}$. Przy czym akcent położony będzie na omówienie zagadnień teoretycznych, a nie stanu faktycznego czy rozstrzygnięcia w konkretnej sprawie.

\subsection{Orzeczenia wydane w oparciu o przepisy Traktatu}

Najstarsza grupa orzeczeń związana jest z problematyką tzw. importu równoległego, polegającego na tym, że towary opatrzone zgodnie z prawem określonym znakiem towarowym w jednym państwie członkowskim (lub poza nim) wwożone są do innego państwa, gdzie - zgodnie z zasadą terytorialnej ochrony znaków towarowych - znak ten jest chroniony niezależnie jako przedmiot prawa tego samego uprawnionego bądź osoby trzeciej. W takich stanach faktycznych ETS wypowiadał się na temat możliwości zakazu przez uprawnionego $\mathrm{w}$ państwie importu sprzedaży towarów pochodzących z zagranicy. Zezwolenie na podniesienie roszczenia zakazowego prowadziłoby bowiem do podziałów we wspólnym rynku.

\footnotetext{
${ }^{17}$ W literaturze polskiej cześć orzecznictwa dotyczącego funkcji znaku towarowego omówiona została przez K. SzCZEPANOWSKA-KOZLOWSKA, Wyczerpanie praw wlasności przemyslowej. Patent i prawo ochronne na znak towarowy, Warszawa 2003, s. 77-97.
} 
Pierwszą koncepcją wypracowaną w takich stanach faktycznych jest pojęcie tzw. 'szczególnego przedmiotu własności przemysłowej i handlowej' (ang. 'specific subject matter of industrial and commercial property'). Po raz pierwszy pojawiło się ono w orzeczeniu w sprawie ochrony praw autorskich - Deutsche Grammophon v. Metro $^{18}$ - niemniej jednak dotyczy wszystkich praw własności przemysłowej. ETS orzekł, iż art. 36 TWE (obecnie art. 30) zezwala na wyjątek od zasady swobodnego przepływu towarów i usług ze względu na wykonywanie praw własności przemysłowej i handlowej tylko w takim zakresie w jakim odstępstwo to jest uzasadnione wykonywaniem praw, które składają się na szczególny przedmiot tej własności ${ }^{19}$.

Pierwszym orzeczeniem z zakresu znaków towarowych odwołującym się do tego terminu było orzeczenie w sprawie Van Zuylen frères v. HAG $\mathrm{AG}^{20}$ (zwanej w literaturze HAG I). ETS doprecyzował, iż szczególny przedmiot własności w zakresie prawa znaków towarowych sprowadza się do ochrony uprawnionego przed naruszeniem ze strony osób, które nie posiadają żadnego tytułu ${ }^{21}$. ETS orzekł jednakże, iż uprawniony do znaku w państwie importu nie może powołać się na wyłączność swojego prawa wobec importera o ile towary w państwie eksportu zostały wyprodukowane legalnie, a znak towarowy ma to samo pochodzenie. Stanowisko to nazwane zostało przez doktrynę 'teorią wspólnego pochodzenia'. Stan faktyczny dotyczył sytuacji, w której pierwotnie znak w państwie eksportu (Niemcy) i importu (Belgia) należał do tego samego uprawnionego, podczas gdy w chwili zaistnienia sporu uprawniony w państwie importu był już niezależnym podmiotem. Specyfika sprawy polegała na tym, iż mienie pierwotnego właściciela znaku - spółki

${ }^{18}$ Wyrok Sądu z 8 czerwca 1971 r. w sprawie Deutsche Grámmophon Gesellschaft mbH przeciwko Metro-SB-Grossßmarket GmbH \& Co. KG, nr C 78-70.

${ }^{14}$ Pkt. 11 wyroku.

20 Wyrok Sądu z 3 lipca 1974 r. w sprawie Van Zuylen frères vs. HAG AG, nr 192-73.

${ }^{21}$ Pkt. 9, 10 wyroku. 
niemieckiej - zostało w Belgii przejęte po II wojnie światowej jako własność nieprzyjaciela, po czym udziały w spółce sprzedane zostały przez państwo belgijskie spółce prywatnej, której odtąd przysługiwał też sporny znak towarowy.

Termin 'szczególny przedmiot własności' rozwinięty został w wyroku Centrafarm v. Winthrop ${ }^{22}$. ETS orzekł, iż w odniesieniu do znaków towarowych 'szczególnym przedmiotem własności' jest gwarantowanie, iż uprawnionemu do znaku przysługuje wyłączne prawo do używania tego znaku w celu wprowadzania towarów opatrzonych znakiem po raz pierwszy do obrotu, a w związku z tym ma ono na celu ochronę uprawnionego przeciwko konkurentom chcącym skorzystać ze statusu $^{23}$ i renomy znaku poprzez sprzedaż produktów opatrzonych tym znakiem nielegalnie ${ }^{24}$. W stanie faktycznym polegającym na imporcie towarów do kraju, gdzie właścicielem znaku była spółka należąca do tego samego koncernu co w kraju eksportu, ETS orzekł, że wprowadzenie ograniczeń w handlu na wspólnym rynku poprzez możliwość zakazania importu towarów z kraju, gdzie zostały one wprowadzone do obrotu przez uprawnionego lub za jego zgodą, nie jest konieczne do zagwarantowania istoty prawa wyłącznego do znaku².

W kolejnym orzeczeniu - Terrapin v. Terranova ${ }^{26}$ ETS pierwszy raz odnosi się wprost do funkcji znaku towarowego stwierdzając, iż podstawową funkcją znaku jest gwarantowanie konsumentowi, że towary opatrzone tym samym znakiem mają to samo źródło pochodzenia $^{27}$. W stanie faktycznym tej sprawy ETS uznał za zgodne $\mathrm{z}$ prawem wspólnotowym zakazanie używania znaku towarowego

${ }^{22}$ Wyrok z dnia 31 października 1974 r. w sprawie Centrafarm BV et Adriaan de Peijper przeciwko Winthrop BV, nr C 16-74.

${ }^{23}$ Jak się wydaje rozumianego jako 'zdolność odróżniająca'.

${ }^{24}$ Pkt. 8 wyroku.

${ }^{25}$ Pkt. 11 wyroku.

${ }^{26}$ Wyrok z dnia 22 czerwca 1976 r. w sprawie Société Terrapin (Overseas) Ltd. przeciwko Société Terranova Industrie CA Kapfere \& Co., nr 119-75.

${ }^{27}$ Pkt. 6 wyroku. 
podobnego do znaku towarowego i nazwy handlowej oraz mogącego wprowadzać w błąd, jeśli pomiędzy oboma podmiotami nie ma powiązań prawnych ani ekonomicznych, prawa do oznaczeń powstały niezależnie oraz nie istnieją porozumienia ograniczające konkurencję $e^{28}$.

Za przełomowe należy uznać orzeczenie Hoffman-La Roche v. Centrafarm $^{29}$, w którym ETS po raz pierwszy użył, cytowanego do dziś, terminu 'podstawowej funkcji znaku towarowego' (angl. 'essential function of the trade-mark'), który wyprowadził $z$ koncepcji „specyficznego przedmiotu ochrony”. ETS stwierdzit, że „[...] podstawową funkcją znaku towarowego jest gwarantowanie konsumentowi lub odbiorcy końcowemu pochodzenia towaru opatrzonego znakiem towarowym, poprzez umożliwienie mu, bez jakiegokolwiek ryzyka konfuzji, odróżnienie tego towaru od towarów, które maja inne źródło. Ta gwarancja pochodzenia oznacza, że konsument lub odbiorca końcowy mogą być pewni, że produkt opatrzony znakiem nie podlegał na poprzednim etapie obrotu ingerencji osób trzecich, które wpłynęłyby na stan produktu. Prawo przysługujące uprawnionemu zakazania użycia znaku towarowego, który może zagrozić gwarancji pochodzenia rozumianej w powyższy sposób, stanowi zatem część specyficznego przedmiotu własności" ${ }^{30}$. Wyrok ten zapoczątkował serię orzeczeń dotyczących przepakowania produktów (w szczególności farmaceutycznych), w których ETS mając za podstawę wyżej zdefiniowaną 'podstawową funkcję znaku towarowego' orzekał, że uprawniony do znaku może podnieść przysługujące mu roszczenia $z$ tytułu praw do znaku, gdy towar został przepakowany a sporny znak towarowy został ponownie nałożony na opakowanie przez osobę trzecią. Niemniej jednak ETS uznał, iż zakaz taki może zostać uznany za ukryte ograniczenia w handlu, jeśli spełnione są łącznie następujące warunki: użycie znaku przez

${ }^{2 x}$ Pkt. 8 wyroku.

${ }^{29}$ Wyrok w sprawie Hoffmann-La Roche \& Co. AG przeciwko Centrafarm Vertriebsgesellschaft Pharmazeutischer Erzeugnisse mbH, nr C 102-77.

${ }^{30}$ Pkt. 7 wyroku. 
uprawnionego i system marketingu, jaki prowadzi przyczynią się do powstania sztucznego podziału rynku, przepakowanie nie może negatywnie wpłynąć na oryginalny stan produktu, uprawniony zostanie uprzednio powiadomiony o zamiarze wprowadzenia na rynek przepakowanego produktu, na nowym opakowaniu wskazany jest podmiot dokonujący przepakowania ${ }^{31}$.

W orzeczeniu Centrafarm v. American Home Products ${ }^{32}$ ETS stwierdził, że ponowne nałożenie znaku na przepakowany towar stanowi zagrożenie dla podstawowej funkcji znaku towarowego ${ }^{33}$, w związku z czym możliwość zakazania takiego działania stanowi specyficzny przedmiot własności, nawet jeśli uprawniony używa różnych znaków towarowych dla tych samych produktów w różnych państwach członkowskich ${ }^{34}$. Niemniej jednak podniesienie roszczeń przez uprawnionego może stanowić ukryte ograniczenia w handlu pomiędzy państwami członkowskimi.

Kolejne znaczące orzeczenie wydane zostało w sprawie S.A. CNL-Sucal v. HAG AG (zwanym w literaturze HAG II) ${ }^{35}$. ETS, mając na względzie rozwój orzecznictwa, uznał za stosowne zmienić swoje wcześniejsze stanowisko zajęte w tym samym stanie faktycznym (sprawa HAG I), nazywane doktryną „wspólnego pochodzenia”. Podkreślając naczelne znaczenie znaku towarowego w systemie niezakłóconej konkurencji, ETS stwierdzil, iż „w takim systemie przedsiębiorstwu musi być przyznana możliwość zachowywania klientów dzięki jakości swoich towarów i usług, co jest możliwe tylko wtedy, gdy istnieją znaki odróżniające, które pozwalają konsumentowi na identyfikacje towaru lub usługi. Aby znak towarowy był w stanie spełnić tę rolę, musi stanowić gwarancję, że wszystkie

${ }^{31}$ Pkt. 14 wyroku.

32 Wyrok z dnia 10 października 1978 w sprawie Centrafarm BV przeciwko American Home Products Corporation, nr C $3 \backslash 78$.

${ }^{3}$ Pkt. 14 wyroku.

${ }^{34}$ Pkt. 17 wyroku.

${ }^{35}$ Wyrok z dnia 17 października 19990 r. w sprawie S.A. CNL-Sucal przeciwko HAG GF AG, nr C-10/89. 
towary nim oznaczone zostały wyprodukowane pod kontrolą jednego przedsiębiorstwa, odpowiedzialnego za ich jakośc” ${ }^{36}$. ETS powtórzył także wcześniejszą formułą specyficznego przedmiotu własności. W konsekwencji stwierdził, że podstawowa funkcja znaku towarowego zostałaby zagrożona, jeśli uprawniony nie mógłby wykonywać swojego prawa wobec towarów importowanych opatrzonych znakiem identycznym lub grożącym wprowadzeniem w błąd $\mathrm{o}$ ile towary te pochodzą z przedsiębiorstwa niezależnego ekonomicznie i prawnie. W takiej sytuacji konsumenci nie mogliby w pewny sposób identyfikować pochodzenia towarów a właściciel znaku w państwie importu uznany byłby za podmiot odpowiedzialny za niską jakość towarów, która w rzeczywistości od niego nie zależała $^{37}$. Bez znaczenia jest fakt, że znaki w państwie eksportu i importu należały pierwotnie do jednego przedsiębiorstwa.

Formuła specyficznego przedmiotu własności i podstawowej funkcji znaku towarowego została powtórzona w orzeczeniu Deutsche Renault v. Audi ${ }^{38}$ w kontekście ryzyka wprowadzenia w błąd przez oznaczenie numeryczne użyte jako oznaczenie odróżniające towaru w innym języku niż zarejestrowany wcześniej znak towarowy. ETS stwierdził, że specyficzny przedmiot własności polega na ochronie uprawnionego przed ryzykiem wprowadzenia w błąd, które pozwoliłoby osobom trzecim czerpać nieuprawnioną korzyść $\mathrm{z}$ renomy towarów pochodzących $\mathrm{z}$ przedsiębiorstwa uprawnionego do znaku towarowego.

W orzeczeniu IHT International v. Ideal-Standard ${ }^{39}$ ETS rozwinął rozumienie źródła pochodzenia towarów, które ma gwarantować użycie znaku towarowego. Decydująca jest możliwość sprawo-

\footnotetext{
${ }^{36}$ Pkt. 14 wyroku.

${ }^{37}$ Pkt. 15 i 16 wyroku.

${ }^{38}$ Wyrok z dnia 30 listopada 1993 r. w sprawie Deutsche Renault AG przeciwko Audi AG, nr C-317/91.

${ }^{39}$ Wyrok z dnia 22 czerwca 1994 r. w sprawie IHT Internationale Heiztechnik GmbH and Uwe Danzinger przeciwko Ideal-Standard GmbH i Wabco Standard $\mathrm{GmbH}, \mathrm{nr}$ C-9/93.
} 
wania kontroli nad jakością towarów, a nie faktyczne jej sprawowanie $^{40}$. Dlatego podstawową funkcję znaku towarowego należy uznać za niezagrożoną, gdy produkty wprowadzane są do obrotu nie tylko przez samego uprawnionego, ale jego licencjobiorcę, spółkę zależną, dystrybutora, etc. $Z$ drugiej strony, jeśli oznaczenia identyczne bądź wprowadzające w błąd należą do podmiotów niezależnych, nawet jeśli pierwotnie można było je przypisać jednemu przedsiębiorstwu, uprawniony w państwie importu może powołać się na wyłączność swojego prawa.

\subsection{Orzeczenia wydane po wejściu w życie Dyrektywy}

Pierwszym orzeczeniem wydanym na podstawie Dyrektywy był wyrok w połączonych sprawach Bristol-Myers Squibb v. Paranova ${ }^{41}$ odnoszący się także do importu równoległego farmaceutyków i ich przepakowania. ETS przeprowadzał w nim wykładnię art. 7 Dyrektywy, dotyczącego wyczerpania praw do znaku towarowego ${ }^{42}$. Po pierwsze ETS orzekł, iż przepis ten w sposób całościowy reguluje wyczerpanie praw do znaku towarowego, w związku z czym na jego podstawie ma odbywać się ocena możliwości zakazania importerowi sprzedaży towaru wprowadzonego do obrotu w innym Państwie Członkowskim przez uprawnionego do znaku lub za jego zgodą, w sytuacji gdy towar został przepakowany i ponownie opatrzony

${ }^{40}$ Pkt. 38 wyroku.

${ }^{41}$ Wyrok z dnia 11 lipca 1996 r. w połączonych sprawach Bristol-Myers Squibb przeciwko Paranova A/S, nr C-427/93, C. H. Boehringer Sohn, Boehringer Ingelheim KG i Boehringer Ingelheim A/S przeciwko Paranova A/S, nr (C-429/93) oraz Bayer Aktiengesellschaft i Bayer Denmark A/S przeciwko Paranova A/S, nr C-436/93.

${ }^{42}$ Art. 7.1: Znak towarowy nie uprawnia właściciela do zakazania używania tego znaku w odniesieniu do towarów, które zostały wprowadzone do obrotu na terytorium Wspólnoty pod tym znakiem towarowym przez właściciela lub za jego zgodą. 2. Ustęp 1 nie ma zastosowania, jeżeli właściciel ma prawnie uzasadnione powody, aby sprzeciwiać się dalszemu obrotowi towarami, szczególnie w przypadku gdy stan towarów zmienił się lub pogorszył po wprowadzeniu ich do obrotu. 
znakiem towarowym bez zgody uprawnionego. Niemniej jednak Dyrektywa jako prawo wtórne musi być interpretowana w świetle postanowień TWE, co w przypadku art. 7 Dyrektywy oznacza odniesienie go do ówczesnego art. 36 TWE. ${ }^{43}$ ETS stwierdził także, że celem obu przepisów jest wyważenie podstawowego interesu związanego $\mathrm{z}$ ochroną praw do znaku i interesów ucieleśnionych w zasadzie swobodnego przepływu towarów, w związku z czym mają być one interpretowane w taki sam sposób ${ }^{44}$.

W konsekwencji ETS zdecydował o kontynuacji wcześniejszej linii orzeczniczej opartej na formule specyficznego przedmiotu własności i podstawowej funkcji znaku towarowego, z których wypływał wniosek o dopuszczalności powołania się na prawa do znaku w sytuacji przepakowania towaru i ponownego nałożenia znaku towarowego, o czym stanowi art. 7 (2) Dyrektywy. ETS powtórzył za rozstrzygnięciem w sprawie Hoffman-La Roche v. Centrafarm, że uprawniony nie może zakazać importerowi wprowadzenia towarów do obrotu o ile spełnione są następujące warunki - wykonywanie praw do znaku, mając na uwadze system marketingu przyjęty przez uprawnionego, przyczyni się do sztucznego podziału rynków pomiędzy Państwami Członkowskimi, przepakowanie nie może niekorzystnie wpłynąć na oryginalny stan produktu, właściciel znaku został uprzednio powiadomiony o wprowadzeniu na rynek towaru przepakowanego, a nowe opakowanie wskazuje, kto dokonał przepakowania ${ }^{45}$. ETS w omawianym orzeczeniu doprecyzował rozumienie tych okoliczności. W odniesieniu do funkcji znaku towarowego istotne jest stwierdzenie, że za sztuczny nie zostanie uznany podział rynku, jeśli właściciel znaku zakaże importu towarów przepakowanych, kiedy takie działanie jest uzasadnione potrzebą zabezpieczenia podstawowej funkcji znaku towarowego ${ }^{40}$. ETS sprecyzował także, że podstawowa funkcja znaku towarowego rozumia-

\footnotetext{
${ }^{43}$ Pkt. 24-28 wyroku.

" Pkt. 40 wyroku.

${ }^{45}$ Pkt. 49 wyroku.

${ }^{\text {th }}$ Pkt. 57 wyroku.
} 
na jako gwarancja pochodzenia nie jest zagrożona, jeśli przepakowanie było przeprowadzone w warunkach, które nie mogą wpłynąć na oryginalny stan produktu ${ }^{47}$. Nowością jest stwierdzenie, iż nawet jeśli nowe opakowanie zawiera dane podmiotu dokonującego przepakowania, możliwe jest, że renoma znaku, a tym samym uprawnionego, może zostać zagrożona przez niewłaściwy wygląd przepakowanego produktu. „W takiej sytuacji, słuszny interes (angielskie 'legitimate') związany ze specyficznym przedmiotem własności uprawnia właściciela do zakazania wprowadzenia na rynek produktu" ${ }^{\text {"48 }}$ Można więc przyjąć ostrożnie, że przynajmniej na gruncie art. 7 (2) Dyrektywy chroniona jest nie tylko funkcja odróżniająca, lecz także reklamowa.

Dwa kolejne orzeczenia wydane tego samego dnia - w sprawie MPA Pharma v. Rhône-Poulenc ${ }^{49}$ oraz Eurim-Pharm v. Beiersdorf ${ }^{50}$ odwołują się co do istoty do orzeczenia Bristol-Myers Squibb v. Paranova. Pytania sądu krajowego ograniczyły się do art. 30 i 36 TWE, choć - jak wskazał ETS - stan faktyczny powinien być rozpatrywany w świetle art. 7 Dyrektywy.

Sprawa Parfums Christian Dior vs Evora ${ }^{51}$ dotyczyła reklamy oryginalnych towarów Dior ${ }^{52}$. Podczas jednej z akcji promocyjnych niezależny sprzedawca umieścił w ulotce reklamowej wśród innych oferowanych towarów wizerunki kosmetyków Dior. Po pierwsze ETS stwierdził, że w świetle art. 5 i 7 Dyrektywy, wyczerpanie praw

\footnotetext{
${ }^{47}$ Pkt. 67 wyroku.

${ }^{4 k}$ Pkt. 75 wyroku.

${ }^{49}$ Wyrok Sądu z dnia 11 lipca 1996 r. w sprawie MPA Pharma GmbH przeciwko Rhône-Poulenc Pharma GmbH, nr C-232/94.

50 Wyrok Sądu z dnia 11 lipca 1996 r. w polączonych sprawach Eurim-Pharm Arzneimittel GmbH przeciwko Beiersdorf AG, nr C-71/94, Boehringer Ingelheim KG, nr C-72/94, oraz Farmitalia Carlo Erba GmbH, nr C-73/94.

${ }^{{ }_{1}}$ Wyrok w sprawie Parfums Christian Dior S.A. i Parfums Christian Dior BV przeciwko Evora BV, nr C-337/95.

s2 Pozyskanych wprawdzie w drodze importu równoległego, ale dopuszczalność ich sprzedaży nie była kwestionowana.
} 
do znaku obejmuje nie tylko możliwość dalszej sprzedaży ale także korzystanie ze znaku w celu zwrócenia uwagi odbiorców na dalszą komercjalizację towarów ${ }^{53}$. W odpowiedzi na kolejne pytania dotyczące $w$ istocie naruszenia funkcji reklamowej znaku ETS udzielił odpowiedzi dość ogólnikowej, unikając zajęcia jednoznacznego stanowiska. Choć przywołał orzeczenie Bristol-Myers Squibb v. Paranova, z którego wynika że ochrona renomy znaku wchodzi w zakres specyficznego przedmiotu własności, w tej sprawie wyprowadził jedynie wniosek, że właściciel znaku może powołać się na art. 7 (2) Dyrektywy przeciwko sprzedawcy, który zwyczajowo oferuje towary tego samego rodzaju, ale niekoniecznie tej samej jakości co uprawniony do znaku, a korzysta ze znaku w celu przyciągnięcia klientów do ich dalszej komercjalizacji, o ile poważnie narusza renomę $z n a k u{ }^{54}$. Kryterium 'poważnego' naruszenia nie zostało wystarczająco określone, by wnioskować o zakresie ochrony funkcji reklamowej znaku. Wydaje się jednak, iż można przyjąć, że ETS na gruncie art. 7 (2) Dyrektywy dopuszcza ochronę funkcji reklamowej, gdy nie istnieje ryzyko wprowadzenia w błąd, w sytuacjach, kiedy znak posiada ustaloną renomę.

Orzeczenia Frits Loendersloot v. George Ballentine ${ }^{55}$ dotyczyło przepakowania wyrobów alkoholowych, które było uzasadnione, zdaniem ich odsprzedawcy, przede wszystkim koniecznością usunięcia numerów identyfikacyjnych znajdujących się na oryginalnych opakowaniach i butelkach. Pomimo odmienności stanu faktycznego, ETS powołał się na wcześniejsze orzeczenia dotyczące przepakowania produktów farmaceutycznych i co do zasady orzekł w taki sam sposób opierając się na koncepcji specyficznego przedmiotu własności i podstawowej funkcji znaku towarowego. Znaczącą różnicą ma być jedynie kryterium konieczności dokonania przepakowania. Podczas gdy w przypadku farmaceutyków należy ją badać

${ }^{53}$ Pkt. 38 wyroku.

${ }^{54}$ Pkt. 48 wyroku.

${ }^{55}$ Wyrok Sądu z 11 listopada 1997 r. w sprawie Frits Loendersloot przeciwko George Ballantine \& Son Ltd and Others, nr C-349/95. 
w sposób obiektywny, w stanie faktycznym takim jak w tej sprawie należy wziąć pod uwagę, czy przepakowanie było konieczne, by chronić źródła zaopatrzenia importera równoległego, i aby umożliwić sprzedaż towarów na różnych rynkach państw Wspólnoty ${ }^{56}$. Zdaniem ETS nie jest spełniony warunek konieczności przepakowania, jeśli stosowne zasady w danym Państwie Członkowskim wymagają jedynie dodatkowych informacji. Zdaniem ETS wystarczy wtedy dodać odpowiednią etykietę ${ }^{57}$.

Kolejne znaczące orzeczenie - Puma v. Sabel ${ }^{58}$ - zapadło w zupełnie odmiennym stanie faktycznym. ETS przeprowadzał interpretację art. 4 (1) (b) Dyrektywy, a sprawa dotyczyła zdolności rejestrowej znaku słowno-graficznego przedstawiającego wizerunek pumy z umieszczonym pod nim napisem Sabel, podobnego do zarejestrowanego znaku graficznego przedstawiającego skaczącą pumę. Pytanie sądu krajowego dotyczyło interpretacji sformułowania ,prawdopodobieństwa skojarzenia” pomiędzy znakami, które znalazło się w tekście Dyrektywy obok sformułowania „prawdopodobieństwa” konfuzji zarówno w art. 4 (1) (b) ${ }^{59}$, jak i art. 5 (1) (b). Ochronę przed ryzykiem wprowadzenia $w$ błąd, tj. sytuacji kiedy odbiorca znaku myli oznaczenia („,bezpośrednie wprowadzenie w błąd”) albo sądzi, że oba oznaczenia pochodzą $\mathrm{z}$ powiązanych ze sobą przedsiębiorstw (,pośrednie wprowadzenie w błąd”), traktuje się jako emanację ochrony funkcji odróżniającej znaku. Przyznanie ochrony sięgającej dalej niż ryzyko konfuzji należałoby - jak się wydaje - uznać za roz-

${ }^{56}$ Pkt. 38 wyroku.

${ }^{57}$ Pkt. 46 wyroku.

${ }^{58}$ Wyrok z dnia 11 listopada 1997 r. w sprawie Sabel BV przeciwko Puma AG, Rudolf Dassler Sport, nr C-251/95.

${ }^{54}$ Art. 4: Każde Państwo Członkowskie może ponadto postanowić, że znak towarowy nie podlega rejestracji, a za nieważny uznaje się już zarejestrowany znak, jeżeli: $[\ldots]$ b) z powodu swej identyczności z wcześniejszym znakiem towarowym lub podobieństwa do niego oraz identyczności z towarami lub usługami objętymi znakiem towarowym lub podobieństwa do nich, istnieje prawdopodobieństwo wprowadzenia w błąd opinii publicznej, które obejmuje prawdopodobieństwo skojarzenia z wcześniejszym znakiem towarowym. 
szerzenie ochrony również na inne funkcje znaku. Do stwierdzenia naruszenia prawa niekonieczne byłoby zatem podważenie znaku jako gwarancji źródła pochodzenia towaru. ETS uznał jednakże, że koncepcja „prawdopodobieństwa skojarzeń" nie stanowi alternatywy dla ,prawdopodobieństwa konfuzji”, ale służy zdefiniowaniu jego zakresu $^{60}$. Nie wystarczy zatem zaistnienie możliwości asocjacji między znakami, aby stwierdzić istnienie możliwości konfuzji ${ }^{61}$. Wydaje się zatem, iż ETS uznał, że chroniona jest wyłącznie funkcja odróżniająca poprzez zakaz wprowadzenia w błąd co do pochodzenia towaru.

W kolejnej sprawie dotyczącej oceny prawdopodobieństwa konfuzji - Canon v. Metro ${ }^{62}$ - powołując się na pojęcie podstawowej funkcji znaku towarowego rozumianej jako gwarantowanie identyfikacji źródła pochodzenia, art. 2 Dyrektywy oraz Pkt. 10 Preambuły Dyrektywy ETS stwierdził, że prawdopodobieństwo konfuzji jest wyłączone tylko wtedy, gdy odbiorcy nie traktują towarów opatrzonych znakiem jako pochodzących $\mathrm{z}$ tego samego przedsiębiorstwa lub przedsiębiorstw powiązanych. Sam fakt przypisywania ich różnym miejscom produkcji nie jest wystarczający ${ }^{63}$.

Orzeczenie BMW v. Roland Deenik ${ }^{64}$ dotyczyło użycia znaku towarowego do reklamy przez niezależny podmiot sprzedaży używanych samochodów BMW oraz usług polegających na naprawie samochodów tej marki. W odniesieniu do sprzedaży używanych samochodów ETS orzekał na podstawie art. 7 (2) Dyrektywy. Powołując się na formułę specyficznego przedmiotu własności wyrażającą się w ochronie właściciela przed czerpaniem przez osoby trzecie korzyści ze zdolności odróżniającej i renomy znaku towarowego, ETS stwierdził, iż fakt czerpania korzyści z użycia cudzego znaku

(") Pkt. 18 wyroku.

${ }^{61}$ Pkt. 26 wyroku.

${ }^{62}$ Wyrok z dnia 29 września 1998 r. w sprawie Canon Kabushiki Kaisha przeciwko Metro-Goldwyn-Mayer Inc., nr C-39/97.

${ }^{6.3}$ Pkt. 29 i 30 wyroku.

${ }^{\text {of }}$ Wyrok z dnia 23 lutego 1999 r. w sprawie Bayerische Motorenwerke AG (BMW) i BMW Nederland BV przeciwko Ronald Karel Deenik, nr C-63/97. 
towarowego w reklamie sprzedaży używanych samochodów BMW polegającej na zapożyczeniu 'poczucia jakości' (uosobionej w znaku towarowym) dla swojej działalności, nie stanowi „uzasadnionych powodów" w rozumieniu art. 7 (2) Dyrektywy, o ile reklama ta jest uczciwa i poprawna, oraz gdy użycie znaku nie powoduje ryzyka wywołania u odbiorców przekonania o handlowych powiązaniach między przedsiębiorstwami ${ }^{65}$. Wydaje się zatem, że ETS - w odniesieniu do art. 7 (2) Dyrektywy - ograniczył ochronę znaku towarowego do jego funkcji odróżniającej, o ile działania osoby trzeciej nie noszą znamienia ogólne pojętej nieuczciwości. Posłużenie się znakiem wyłącznie dla zakomunikowania rodzaju prowadzonej działalności ETS nazwał ,informacyjnym” i podkreślił, że przedsiębiorca nie czerpie w ten sposób nienależnej korzyści ze zdolności odróżniającej i renomy znaku. W identyczny sposób ETS ocenił dopuszczalność użycia znaku towarowego do poinformowania klientów o świadczeniu usług z zakresu naprawy samochodów marki BMW. Orzekając w odniesieniu do art. 6 (1) (c) Dyrektywy ${ }^{66}$, stanowiącego o ograniczeniach prawa do znaku, ETS uznał co do istoty, $\mathrm{iz}$ - o ile nie istnieje ryzyko wprowadzenia w błąd - nie ma podstaw do zakazania osobie trzeciej użycia informacyjnego znaku.

W orzeczeniu Windsurfing Chiemsee v. Huber and Attenberger $^{67}$ ETS nie odwołuje się wprost do specyficznego przedmiotu

${ }^{65}$ Pkt. 52 i 53 wyroku.

(6) Art. 6 (1): Ograniczenie skutków znaku towarowego. 1. Znak towarowy nie upoważnia właściciela do zakazania stronie trzeciej używania w obrocie handlowym: a) jej własnego nazwiska lub adresu; b) wskazówek dotyczących rodzaju, jakości, ilości, zamierzonego przeznaczenia, wartości, pochodzenia geograficznego, daty produkcji towarów lub świadczenia usług, lub innych cech charakterystycznych towarów lub usług; c) znaku towarowego, jeżeli jest to niezbędne dla wskazania zamierzonego przeznaczenia towaru lub usługi, zwłaszcza akcesoriów lub części zamiennych; pod warunkiem że osoba ta używa ich zgodnie z uczciwymi praktykami w handlu i przemyśle.

${ }^{67}$ Wyrok z dnia 4 maja 1999 r. w polączonych sprawach Windsurfing Chiemsee Produktions- und Vertriebs GmbH (WSC) przeciwko Boots- und Segelzubehoor Walter Huber, nr C-108/97 i Franz Attenberger, nr C-109/97. 
własności ani podstawowej funkcji znaku towarowego. Orzeczenie dotyczy zdolności rejestrowej oznaczenia geograficznego w kontekście art. 3 (1) (c) i art. 3 (3) Dyrektywy ${ }^{68}$. Co istotne dla rozważań niniejszego artykułu, ETS stwierdził, iż oznaczenie geograficzne uzyskuje wtórną zdolność odróżniającą na takich samych zasadach jak inne oznaczenia, tj. o ile w świadomości odbiorców wskazuje na pochodzenie konkretnego towaru $\mathrm{z}$ określonego przedsiębiorstwa a w konsekwencji służy do odróżniania towarów pochodzących $\mathrm{z}$ różnych przedsiębiorstw ${ }^{69}$. Tylko w przypadku oznaczeń geograficznych szczególnie dobrze znanych konieczne jest zastosowanie bardziej restrykcyjnych kryteriów nabycia zdolności rejestrowej. Konieczne jest wykazanie intensywnego, długotrwałego i utrwalonego użycia ${ }^{70}$. Tym samym ETS potwierdził znaczenie podstawowej funkcji znaku towarowego, będącej jednocześnie jego elementem konstytutywnym, tj. zdolności odróżniania towarów pochodzących z różnych przedsiębiorstw zrównując przesłanki oceny posiadania tej zdolności w odniesieniu do wszystkich oznaczeń, w tym oznaczeń geograficznych.

Rozstrzygnięcie kolejnego orzeczenia - Lloyd v. Klijsen ${ }^{71}$ - rozwija zagadnienie związku zdolności odróżniającej znaku oraz oce-

${ }^{\text {c* Art. }} 3$ (1): Podstawy odmowy lub stwierdzenia nieważności rejestracji 1. Nie są rejestrowane, a za nieważne uznaje się już zarejestrowane: [...] c) znaki towarowe, które składają się wyłącznie z oznaczeń lub wskazówek mogących służyć w obrocie do oznaczania rodzaju, jakości, ilości, przeznaczenia, wartości, pochodzenia geograficznego lub czasu produkcji towaru lub świadczenia usługi, lub innych właściwości towarów lub usług; 3. Nie można odmówić rejestracji znaku towarowego ani stwierdzać jego nieważności zgodnie z ust. 1 lit. b), c) lub d), jeżeli przed datą złożenia wniosku o rejestrację i w następstwie jego używania znak ten uzyskał charakter odróżniający. Każde Państwo Członkowskie może ponadto postanowić, że niniejszy przepis będzie miał także zastosowanie, kiedy charakter odróżniający został uzyskany po dacie złożenia wniosku o rejestrację lub po dacie rejestracji.

${ }^{19}$ Pkt. 46-49 wyroku.

7" Pkt. 50 wyroku.

${ }^{7}$ Wyrok z dnia 22 czerwca 1999 r. w sprawie Lloyd Schuhfabrik Meyer \& Co. GmbH przeciwko Klijsen Handel BV, nr C-342/97. 
ny ryzyka konfuzji. Zdolność odróżniająca to zdolność do pełnienia głównej funkcji znaku towarowego, tj. odróżniania towarów pochodzących z różnych przedsiębiorstw. Różne znaki towarowe, w zależności od stopnia fantazyjności ich komponentów, posiadają różną zdolność odróżniającą. Wpływa na nią również znajomość i pozycja znaku w odbiorze klientów. ETS stwierdził, iż im większa zdolność odróżniającą znaku towarowego, tym większe ryzyko konfuzji. ETS orzekł, że ,jest możliwe, że zaledwie fonetyczne podobieństwo pomiędzy znakami może stwarzać prawdopodobieństwo konfuzji w rozumieniu art. 5 (1) (b) Dyrektywy. Jest ono tym większe im bardziej podobne są towary lub usługi opatrzone znakiem i im większą zdolność odróżniającą posiada wcześniejszy znak towarowy. Oceniając zdolność odróżniającą znaku, tym samym oceniając czy jest ona wysoka, należy dokonać całościowej oceny mniejszej lub większej zdolności do identyfikowania towarów lub usług, dla których znak został zarejestrowany jako pochodzących $z$ określonego przedsiębiorstwa, a w konsekwencji odróżniania tych towarów lub usług od towarów pochodzących $\mathrm{z}$ innych przedsiębiorstw. Dokonując tej oceny należy zwrócić uwagę na wszystkie istotne czynniki, w szczególności cechy samego znaku, włączając $w$ to posiadanie bądź nie elementów deskryptywnych odnoszących się do towarów i usług, dla których znak został zarejestrowany. Nie jest możliwe odwołanie się do ogólnych warunków, na przykład określonego procentowo stopnia rozpoznawalności znaku w stosownym sektorze odbiorców, aby ocenić, że znak posiada silną zdolność odróżniającą" 72 .

W wyroku Pharmacia \& Upjohn v. Paranova ${ }^{73}$ ETS uzupełnił swoje orzeczenia wydane w sprawach Hoffman-La Roche v. Centrafarm i orzeczenie Bristol-Myers Squibb v. Paranova stwierdzając, że w przypadku wyrobów farmaceutycznych możliwość zakazania przez uprawnionego zamiany przez importera równoległego

${ }^{72}$ Pkt. 28 wyroku.

${ }^{73}$ Wyrok Sądu z dnia 12 października 1999 r w sprawie Pharmacia \&Upjohn S.A. przeciwko Paranova A/S, nr C-379/97. 
znaku towarowego używanego w państwie eksportu na oznaczenie używane przez uprawnionego w państwie importu, zależy od tego, czy w chwili wprowadzenia towarów do obrotu taka zmiana była obiektywnie konieczna ${ }^{74}$.

W wyroku Baby-Dry ${ }^{75}$ dotyczącym odwołania od Sądu I Instancji, ETS orzekal na podstawie art. 7 (1) (c) Rozporządzenia ${ }^{76}$. Stwierdził, że istotą zakazu rejestracji oznaczeń deskryptywnych jest brak zdolności do pełnienia funkcji identyfikacji przedsiębiorstwa, z którego pochodzą towary, a przez to brak odróżniającego charakteru koniecznego do spełniania tej funkcjiin. ETS uznał, iż określenie Baby-Dry, które miało zostać zarejestrowane dla pieluszek dla dzieci jako całość nie może zostać uznane za deskryptywne, jako że sformułowanie to nie jest stosowane w języku codziennym do wskazywania na pieluszki dziecięce ani na ich cechy ${ }^{78}$.

W orzeczeniu Merz\&Krell ${ }^{79}$ ETS podkreślił fakt, iż sformułowane w orzecznictwie pojęcie podstawowej funkcji znaku towarowego zostało włączone do prawa wspólnotowego jako art. 2 Dyrektywy mówiący o zdolności rejestrowej oznaczenia ${ }^{80}$, oraz że celem ochrony ucieleśnionej w zarejestrowanym znaku towarowym jest w szczególności gwarantowanie funkcji znaku towarowego jako oznaczenia pochodzenia. W tej sprawie ETS orzekał o przeszkodach reje-

${ }^{74}$ Pkt. 46 wyroku.

${ }^{75}$ Wyrok Sądu z dnia 20 września 2001 r. w sprawie Procter \& Gamble Company przeciwko Office for Harmonisation in the Internal Market (Trade Marks and Designs) (OHIM), nr C-383/99 P.

7" Art. 7. 1: Bezwzględne podstawy odmowy rejestracji. 1. Nie są rejestrowane: [...] c) znaki towarowe, które składają się wyłącznie z oznaczeń lub wskazówek, mogących służyć w obrocie do oznaczania rodzaju, jakości, ilości, przeznaczenia, wartości, pochodzenia geograficznego lub czasu produkcji towaru lub świadczenia usługi, lub innych właściwości towarów lub usług.

${ }^{77}$ Pkt. 37 wyroku.

${ }^{78}$ Pkt. 42 wyroku.

${ }^{79}$ Wyrok Sądu z dnia 4 października w sprawie Merz\& Krell GmbH\& Co., nr C-517/99.

s) Pkt. 23 wyroku. 
stracji wyrażonych w art. 3 (1) (d) Dyrektywy ${ }^{81}$, tj. rejestracji oznaczeń, które stały się potoczne w języku codziennym lub praktykach handlowych. Oznaczeniem, które zostało zgłoszone do rejestracji było słowo „Bravo” dla materiałów piśmienniczych. ETS uznał, iż powyższą przeszkodę rejestracji należy każdorazowo odnosić do towarów lub usług, które mają być objęte rejestracją. ${ }^{82}$ ETS uznał, ze znaki lub inne sformułowania będące znakami towarowymi, które stały się potoczne w odniesieniu do towarów lub usług nimi opatrzonych nie są w stanie ich odróżniać i dlatego nie są w stanie spełniać podstawowej funkcji znaku towarowego - chyba że zyskają zdolność odróżniającą poprzez ich używanie, o czym stanowi art. 3 (3) Dyrektywy ${ }^{83}$. Powyższa zasada nie jest ograniczona do oznaczeń opisujących właściwości lub cechy tych towarów lub usług ${ }^{84}$.

Jako że sprawa Boehringer v. Swingward ${ }^{85}$ dotyczyła zmian dokonanych przez importerów równoległych w oryginalnych opakowaniach i ulotkach informacyjnych farmaceutyków ETS dokonał przeglądu swego dotychczasowego orzecznictwa. Miał bowiem odpowiedzieć na pytanie, czy uprawniony może dokonać zmian w opakowaniu, po pierwsze jeśli nie są naruszone jego interesy wyrażające się w ochronie funkcji odróżniającej znaku oraz gwa-

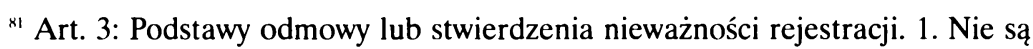
rejestrowane, a za nieważne uznaje się już zarejestrowane: [...]. d) znaki towarowe, które składają się wyłącznie z oznaczeń lub wskazówek, które weszły do języka potocznego lub są zwyczajowo używane w uczciwych i utrwalonych praktykach handlowych.

${ }^{82}$ Pkt. 31 wyroku.

${ }^{83}$ Pkt. 37 wyroku.

${ }^{* 4}$ Pkt. 41 wyroku.

${ }^{85}$ Wyrok Sądu z dnia 23 kwietnia 2002 r. w połączonych sprawie Boehringer Ingelheim KG i Boehringer Ingelheim Pharma KG przeciwko Swingward Ltd, Boehringer Ingelheim KG i Boehringer Ingelheim Pharma KG przeciwko Dowelhurst Ltd, Glaxo Group Ltd przeciwko Swingward Ltd, Glaxo Group Ltd i the Welcome foundation Ltd przeciwko Dowelhurst Ltd, SmithKline Beecham plc, Beecham Group plc i SmithKline \& French Laboratories Ltd przeciwko Dowelhurst Ltd oraz pomiędzy Eli Lilly and Co. Przeciwko Dowehurst Ltd, nr C-143/00. 
rantowania jakości produktu, po drugie, jeśli dokonanie zmian w opakowaniu nie było konieczne ${ }^{86}$. ETS przypomnial, że w wyroku Hoffman-La Roche v. Centrafarm przepakowanie, które ze swej istoty zagraża funkcji gwarantowania pochodzenia produktu, traktowane jest jako prejudycjalne wobec specyficznego przedmiotu własności. Oznacza to, że nawet jeśli nie ma jego naruszenia, uprawniony może zakazać wprowadzenia na rynek towaru przepakowanego. Uprawnienie to ograniczone jest warunkiem, iż zakaz ten nie stanowi ukrytych ograniczeń w handlu w Państwach Członkowskich w rozumieniu art. $30 \mathrm{TWE}^{87}$. Za ukryte ograniczenia należy uznać zakaz wprowadzenia na rynek przepakowanego produktu, jeśli prowadzi to do sztucznych podziałów rynku między Państwami Członkowskimi, a dodatkowo przepakowanie nie narusza słusznych interesów uprawnionego, w szczególności nie wpływa negatywnie na oryginalny stan produktu i renomę znaku towarowego ${ }^{88}$. Do sztucznego podziału rynku dochodzi natomiast, jeśli zakaz dotyczy produktów, których przepakowanie było konieczne do wprowadzenia na rynek w państwie importu. W konsekwencji uprawniony może zakazać wprowadzenia do obrotu towarów przepakowanych, chyba że przepakowanie było konieczne a słuszne interesy uprawnionego są należycie zabezpieczone ${ }^{89}$. ETS odpowiada zatem $w$ niniejszej sprawie, iż uprawnionemu przysługuje zakaz wprowadzania do obrotu przepakowanych produktów farmaceutycznych, jeśli nie przyczynia się to do sztucznego podziału rynku między państwami członkowskimi ${ }^{\text {(1) }}$. Jeśli nie ma naruszenia specyficznego przedmiotu własności, kryterium decydującym jest przyczynienie się do sztucznego podziału rynku. Przepakowanie jest obiektywnie konieczne, jeśli bez niego dostęp do rynku lub jego znaczącej części byłby utrudniony, również

\footnotetext{
*o Pkt. 20 wyroku.

${ }^{87}$ Pkt. 30 i 31 wyroku.

${ }^{s *}$ Pkt. 32 wyroku.

${ }^{89}$ Pkt. 34 wyroku.

${ }^{\left.{ }^{*}\right)}$ Pkt. 35 wyroku.
} 
w wyniku silnego oporu klientów do zakupu towarów opatrzonych jedynie dodatkowymi etykietami ${ }^{11}$.

Pytania sądu krajowego w niniejszej sprawie dotyczyły także uprzedniego zawiadomienia uprawnionego przez importera równoległego o planowanym przepakowaniu. W ocenie ETS takie zawiadomienie jest konieczne, aby były zabezpieczone interesy uprawnionego. Niedochowanie tego obowiązku skutkuje możliwością zakazu wprowadzenia przepakowanych towarów do obrotu. Zawiadomienie ma być dokonane przez samego importera odpowiednio wcześnie, co zdaniem ETS powinno wynosić 15 dni roboczych ${ }^{92}$.

Kolejne orzeczenie - Merck, Sharp v. Paranova ${ }^{93}$ także dotyczyło przepakowania produktu farmaceutycznego, które nie było konieczne jednak sprzedawalność produktu w opakowaniu oferowanym w państwie eksportu byłaby zagrożona w państwie importu ze względu na uprzedzenia klientów do towarów przeznaczonych na rynek zagraniczny. ETS orzekł, iż zmianę opakowania należy uznać za obiektywnie konieczną, jeśli bez przepakowania dostęp do rynku lub jego znaczącej części byłby utrudniony ze względu na silne uprzedzenia znaczącej części konsumentów do produktów opatrzonych jedynie dodatkowymi etykietami ${ }^{94}$.

Sprawa Hölterhoff v. Freiesleben ${ }^{95}$ dotyczyła użycia cudzego znaku towarowego do celów opisowych. ETS stwierdził, iż nie stanowi naruszenia praw do znaku użycie deskryptywne oznaczenia, jeśli tak użyty znak towarowy nie może być odebrany jako oznaczenie wskazujące na przedsiębiorstwo, z którego pochodzi opatrzony nim towar ${ }^{46}$.

${ }^{91}$ Pkt. 54 wyroku.

${ }^{42}$ Pkt. 68 wyroku.

"3. Wyrok Sądu z dnia 23 kwietnia 2002 r. w sprawie Merck, Sharp \& Dohme $\mathrm{GmbH}$ przcciwko Paranova Pharmazeutika Handels GmbH, nr C-443/99.

"Pkt. 33 wyroku.

". Wyrok Sądu z dnia 14 maja 2002 r. w sprawie Michael Hölterhoff przeciwko Ulrich Freiesleben, $\operatorname{nr} \mathrm{C}-2 / 00$.

* Pkt. 17 wyroku. 
W orzeczeniu Philips v. Remington ${ }^{97}$ ETS zajmował się przeszkodami rejestracji z art. 3 (1) (a), (b), (c), (d) Dyrektywy a sprawa dotyczyła unieważnienia graficznego wizerunku kształtu i górnej części elektrycznej golarki Philips. ETS rozpoczął swój wywód od przypomnienia co stanowi podstawową funkcję znaku towarowego na podstawie dotychczasowego orzecznictwa, stwierdzając jednocześnie, że wynika ona także z brzmienia i struktury różnych przepisów Dyrektywy dotyczących podstaw odmowy rejestracji ${ }^{\text {甲و }}$. Jednocześnie podkreślit, że funkcja gwarantowania pochodzenia jest według pkt. 10 Preambuły Dyrektywy tylko jednym z celów ochrony ${ }^{99}$. ETS stwierdził także, że jeśli oznaczenie ma zdolność odróżniającą bądź ze swojej natury (tzw. pierwotna zdolność odróżniająca) bądź uzyskaną ze względu na używanie (tzw. wtórna zdolność odróżniająca), nie może być zakwalifikowane jako nie będące w stanie odróżniać towarów uprawnionego od oznaczeń innych przedsiębiorstw ${ }^{100}$. W konsekwencji odpowiadając na pytanie sądu krajowego, ETS stwierdził, że nie istnieją oznaczenia nie podlegające wyłączeniu $\mathrm{z}$ rejestracji na podstawie art. 3 (1) (b), (c) (d) oraz art. 3 (3), a nieposiadające zdolności rejestrowej na podstawie art. 3 (1) (a) jako niezdolne do odróżniania towarów i usług ${ }^{101}$.

ETS stwierdził również, że do oceny zdolności odróżniającej znaków przestrzennych stosuje się te same kryteria co w przypadku innych oznaczeń. Cechą konstytutywną znaku ma być bowiem zdolność odróżniania towarów pochodzących $\mathrm{z}$ różnych przedsiębiorstw, a w związku z tym spełniających podstawowy cel gwarantowania pochodzenia produktu ${ }^{102}$. W tej konkretnej sprawie oznacza to, że kształt produktu, który ma zostać zarejestrowany jako znak

\footnotetext{
${ }^{\text {"7 }}$ Wyrok Sądu z dnia 18 czerwca 2002 r. w sprawie Koninklijke Philips Electronics NV przeciwko Remington Consumer Products Ltd, nr C-299/99.

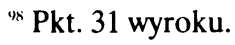

") Pkt. 29 wyroku.

${ }^{100}$ Pkt. 39 wyroku.

'"' Pkt. 40 wyroku.

${ }^{102}$ Pkt. 49 wyroku.
} 
towarowy nie musi posiadać żadnych fantazyjnych dodatków takich jak ozdoba, która nie miałaby celu funkcjonalnego ${ }^{103}$.

W odniesieniu do nabycia tzw. wtórnej zdolności odróżniającej (art. 3 pkt. 3 Dyrektywy) ETS stwierdzil, że jeśli korzystający ze znaku był jedynym dostawcą produktu, szerokie użycie znaku, będącego kształtem tych produktów może być wystarczające do uzyskania przez znak charakteru odróżniającego o ile w rezultacie tego używania znaczącą cześć stosownych odbiorców łączy ten kształt wyłącznie $\mathrm{z}$ określonym przedsiębiorstwem lub sądzi, że towary $\mathrm{o}$ takim kształcie pochodzą $\mathrm{z}$ tego przedsiębiorstwa ${ }^{104}$.

W sprawie Arsenal v. Matthew Reed ${ }^{105}$ ETS miał rozstrzygnąć czy na podstawie art. 5 (1) (a) Dyrektywy naruszeniem praw do znaku jest jakiekolwiek użycie oznaczenia identycznego do zarejestrowanego znaku dla identycznych towarów, czy tylko takie użycie, które narusza interesy uprawnionego. ETS uznał, że wykonywanie prawa na podstawie tego przepisu jest ograniczone do spraw, w których użycie znaku przez osobę trzecią wpływa lub może wpływać na funkcje znaku towarowego, w szczególności na podstawową funkcję znaku towarowego polegającą na gwarantowaniu konsumentom pochodzenia produktu ${ }^{106}$. ETS zdaje się wyprowadzać tę zasadę z pkt. 10 preambuły Dyrektywy, gdzie mowa, iż celem ochrony jest w szczególności gwarancja znaku towarowego jako źródła pochodzenia ${ }^{107}$ oraz brzmienia art. 5 (5) Dyrektywy ${ }^{108}$, z któ-

\footnotetext{
${ }^{103}$ Pkt. 50 wyroku

${ }^{114}$ Pkt. 65 wyroku.

${ }^{105}$ Wyrok Sądu z dnia 12 listopada 2002 r. w sprawie Arsenal Football Club plc przeciwko Matthew Reed, nr C-206/01.

${ }^{11 *}$ Pkt. 51 wyroku.

${ }^{107}$ Pkt. 50 wyroku.

${ }^{110 \times}$ Art. 5 pkt. 5: Ustępy 1-4 nie mają wplywu na przepisy obowiązujące w Państwach Członkowskich, dotyczące ochrony przed używaniem oznaczenia w celach innych niż odróżnienie towarów lub usług, jeżeli używanie tego oznaczenia bez wlaściwego powodu przyniosłoby nieuzasadnioną korzyść lub byłoby szkodliwe dla odróżniająccgo charakteru lub renomy znaku towarowego.
} 
rego wynika, że art. 5 (1) do (4) nie uchybiają przepisom państw członkowskich odnoszących się do ochrony przed użyciem znaku w innym celu niż odróżniania towarów i usług ${ }^{109}$. Stan faktyczny sprawy polegał na sprzedaży pamiątek opatrzonych znakami towarowymi „Arsenal” zarejestrowanymi na rzecz klubu piłkarskiego przez niezależnego sprzedawcę. Sprzedawał on na tym samym stoisku zarówno towary oryginalne jak i opatrzone znakami towarowymi bez zgody uprawnionego, niemniej jednak na stoisku umieszczał zastrzeżenie, że wyłącznie towary opatrzone oficjalnymi metkami Arsenalu stanowią towary oryginalne. ETS uznał, że nałożenie znaku na towary wywołuje wrażenie, że pomiędzy towarami a uprawnionym do znaku jest istotny związek ${ }^{110}$. Tego wrażenia nie wyłącza umieszczone przez sprzedawcę zastrzeżenie. Nawet zakładając, że można je potraktować jako zarzut w procesie o naruszenie prawa do znaków towarowych, możliwe jest, że część konsumentów, w szczególności mających kontakt $\mathrm{z}$ towarami po ich sprzedaży ze stoiska, gdzie umieszczone jest zastrzeżenie, może zinterpretować oznaczenia jako wskazujące na klub Arsenal jako źródło ich pochodzenia $^{\prime \prime \prime}$. ETS wskazał także, że w stanie faktycznym tej sprawy znak towarowy nie stanowi gwarancji, że towary nim opatrzone zostały wyprodukowane lub dostarczone pod kontrolą jednego przedsiębiorstwa odpowiedzialnego za ich jakośćc ${ }^{12}$. Jeśli użycie oznaczenia oddziałuje na funkcję gwarantowania pochodzenia bez znaczenia jest, że może być ono odbierane jako oznaka wsparcia, lojalności, czy przywiązania do właściciela znaku ${ }^{113}$. Tym samym ETS nie odpowiedział wprost na jednoznacznie zadane pytanie sądu krajowego, czy w przypadku znaku identycznego osobie używającej go bez zgody uprawnionego przysługuje zarzut, że oznaczenie to nie wskazuje na pochodzenie towaru. Odpowiedź na tak zadane pyta-

\footnotetext{
${ }^{1149}$ Pkt. 52 wyroku.

"1" Pkt. 56 wyroku.

I"' Pkt. 57 wyroku.

${ }^{112}$ Pkt. 58 wyroku.

${ }^{113}$ Pkt. 61 wyroku.
} 
nie rozstrzygałaby, czy na podstawie art. 5 (1) (a) Dyrektywy chroniona jest tylko funkcja odróżniająca oznaczenia, czy również pozostałe funkcje znaku towarowego. Samo brzmienie przepisu kwestii tej nie rozstrzyga.

Podobnym zagadnieniem zajmował się ETS w sprawie Robelco vs Robeco ${ }^{114}$. ETS stwierdził, że z art. 5 (5) Dyrektwy wynika, że wzmocniona ochrona zdolności odróżniającej lub renomy znaku przeciwko użyciu znaku w innym celu niż odróżnianie towarów lub usług nie podlega harmonizacji ${ }^{115}$.

Orzeczenie Davidoff vs Gofki ${ }^{116}$ dotyczy ochrony znaku renomowanego na podstawie art. 5 (2) Dyrektywy odpowiadającego przeszkodom rejestracji wyrażonym w art. 4 (4) (a) Dyrektywy. Udzielając odpowiedzi na zapytanie sądu krajowego ETS stwierdzil, iż ustawodawstwo krajowe może przewidzieć rozszerzoną ochronę dla znaku renomowanego także w przypadku towarów identycznych i podobnych, a nie tylko odmiennych co wynika $z$ dosłownego brzmienia obu przepisów ${ }^{117}$. W toku swych ustaleń ETS potwierdził także, że ochrona znaku towarowego przed użyciem oznaczenia identycznego dla identycznych towarów jest absolutna, jeśli to użycie narusza lub może naruszyć jedną z funkcji znaku towarowego ${ }^{118}$. Podkreślił także, że silniejsza ochrona przysługująca znakom renomowanym ma na celu ich ochronę przeciwko pogorszeniu zdolności odróżniającej i renomy znaku ${ }^{119}, \mathrm{z}$ czego można wnioskować, iż do dochodzenia tej ochrony nie jest wymagane istnienie ryzyka konfuzji (ETS nie wyraził tego wprost, choć wątpliwości sądu krajowego także dotyczyły tego zagadnienia).

${ }^{114}$ Wyrok Sądu z dnia 21 listopada 2002 r. w sprawie Robelco NV przeciwko Robeco Groep NV, nr C-23/01.

${ }^{115}$ Pkt. 31 wyroku.

${ }^{116}$ Wyrok Sądu z dnia 9 stycznia 2003 r. w sprawie Davidoff \& Cie S.A. i Zino Davidoff S.A. przeciwko Gofkid Ltd, nr C-292/00.

${ }^{117}$ Pkt. 30 wyroku.

${ }^{11}$ Pkt. 28 wyroku.

${ }^{119}$ Pkt. 21 wyroku. 
Sprawa Ansul v. Ajax ${ }^{120}$ dotyczyła używania znaku w rzeczywisty sposób (angl. 'genuine use of a trademark'). ETS uznał, że użycic znaku można uznać za rzeczywiste, jeśli jest zgodne z podstawową funkcją znaku towarowego, którą jest gwarantowanie tożsamości pochodzenia towarów lub usług, dla których znak jest zarejestrowany, w celu stworzenie lub zachowania zbytu tych towarów lub usług; rzeczywistym użyciem nie jest użycie 'symboliczne' wyłączenie w celu zachowania praw do znaku' ${ }^{121}$. ETS uznał także, że w granicach rzeczywistego użycia mieści się nie tylko używanie znaku dla nowych towarów wprowadzanych do obrotu, lecz także w odniesieniu do towarów sprzedanych w przeszłości, jeśli właściciel używa znaku w sposób rzeczywisty dla części, które należą do budowy lub struktury tych towarów lub dla towarów i usług bezpośrednio związanych z towarami sprzedanymi uprzednio, których celem jest zaspokojenie potrzeb klientów tych dóbr ${ }^{122}$.

W sprawie Diffusion v. Sadas ${ }^{123}$ ETS miał zinterpretować pojęcie 'znaku identycznego', którego użycie dla identycznych towarów lub usług stanowi naruszenie praw do znaku - art. 5 (1) (a) Dyrektywy. ETS udzielając odpowiedzi na pytanie sądu krajowego przypomniał, że istotą ochrony udzielanej znakom towarowym jest ochrona podstawowej funkcji znaku towarowego, tj. gwarantowania tożsamości pochodzenia towarów lub usług. Aby ochrona tej funkcja była zapewniona, konieczna jest ochrona uprawnionego przed działaniami konkurentów mającymi na celu uzyskanie nienależnych korzyści ze zdolności odróżniającej i renomy znaku przez sprzedaż towarów bezprawnie opatrzonych znakiem $^{124}$. ETS stwierdził, że ochrona znaku identycznego prze-

${ }^{120}$ Wyrok Sądu z dnia 11 marca 2003 r. w sprawie Ansul BV przeciwsko Ajax Brandbeveiliging BV, nr C-40/01.

${ }^{121}$ Pkt. 43 wyroku.

122 Pkt. 43 wyroku.

${ }^{12.3}$ Wyrok Sądu z dnia 20 marca 2003 r. w sprawie LTJ Diffusion S.A. przeciwsko Sadas Vertbaudet S. A., nr C-291/00.

${ }^{124}$ Pkt. 46 wyroku. 
widziana w art. 5 (1) (a) Dyrektywy dotyczy oznaczeń będących reprodukcją znaku towarowego bez żadnych modyfikacji lub dodatków lub oznaczeń, które postrzegane jako całość, zawierają różnice tak nieznaczne, że mogą być niezauważone przez przeciętnego konsumenta ${ }^{125}$.

Sprawa Linde vs Rado ${ }^{126}$ dotyczyła zdolności odróżniającej znaków przestrzennych. ETS przypomniał, że zdolność odróżniająca to zdolność identyfikowania produktu jako pochodzącego z określonego przedsiębiorstwa, a przez to odróżniania towarów pochodzących z różnych przedsiębiorstw ${ }^{127}$. ETS powtórzył m.in., że znaki przestrzenne nie wymagają zaostrzonego kryterium oceny zdolności odróżniającej ${ }^{128}$.

W sprawie Libertel v. Benelux-Merkenbureau ${ }^{129}$ sąd krajowy pytał m.in. o zdolność odróżniającą koloru per se. ETS przypomniał, że podstawową funkcją znaku towarowego jest gwarantowanie tożsamości pochodzenia towarów lub usług konsumentom lub odbiorcom końcowym, a przez to umożliwianie im bez jakiejkolwiek możliwości wprowadzenia w błąd odróżniania tych towarów lub usług od pochodzących z innego przedsiębiorstwa. ,Znak towarowy musi odróżniać towary lub usługi jako pochodzące z określonego przedsiębiorstwa. W związku z tym należy mieć na uwadze zarówno typowe użycie znaku towarowego jako oznaczenia pochodzenia w stosownej branży i sposobu postrzegania przez reprezentatywnych odbiorców"130. ETS nie wykluczyl, iż kolor per se może posiadać pierwotną zdolność odróżniającą lecz podkreślit, że będzie to miało miejsce w sytuacjach szczególnych, jako że konsumenci nie

${ }^{125}$ Pkt. 54 wyroku.

126 Wyrok Sądu z dnia 8 kwietnia 2003 r. w połączonych sprawach Linde AG, nr C-53/01, Winward Industries Inc. (C-54/01), Rado Uhren AG (C-55/01).

${ }^{127}$ Pkt. 40, 47 wyroku.

${ }^{128}$ Pkt. 49 wyroku.

${ }^{129}$ Wyrok z dnia 6 maja 2003 r. w sprawie Libertel Groep BV przeciwko Benelux-Markenbureau, nr C-104/01.

${ }^{1.30}$ Pkt. 62 wyroku. 
mają zwyczaju łączyć koloru towaru lub koloru opakowania ze źródłem pochodzenia ${ }^{131}$.

W sprawie Adidas-Salomon AG v. Fitnessworld ${ }^{132}$ ETS stwierdził m.in., iż art. 5 (2) Dyrektywy dotyczący rozszerzonej ochrony znaków renomowanych nie wymaga istnienia ryzyka konfuzji. Warunkiem szczególnym jest użycie oznaczenia bez należnego tytułu, które jest szkodliwe dla odróżniającego charakteru znaku lub jego renomy, lub gdy przynosi ono nienależną korzyśćc ${ }^{133}$. Tym samym ETS stwierdził, iż możliwa jest ochrona funkcji odróżniającej znaku bez stwierdzenia ryzyka wprowadzenia w błąd - chroniona jest bowiem - jak można rozumieć - zdolność odróżniająca samego oznaczenia, a nie w odniesieniu do konkretnych towarów. Ochronie podlega także funkcja reklamowa w oderwaniu od funkcji odróżniającej, co wyraża się w ochronie renomy znaku. Konieczny jest jedynie pewien stopień podobieństwa między oznaczeniami, który powoduje, że stosowna część odbiorców łączy oba oznaczenia, co oznacza, że wiążą je oni ze sobą, chociaż nie występuje ryzyko konfuzji ${ }^{134}$. ETS stwierdził również, że fakt odbierania znaku towarowego jako ozdoby nie jest sam w sobie przeszkodą do udzielenia mu ochrony. Zdaniem ETS, jeśli znak odbierany byłby wyłącznie jako ozdoba, potencjalni odbiorcy niekoniecznie łączyliby to oznaczenia ze znakiem renomowanym, w związku z czym stan faktyczny nie spełniałby jednej z przesłanek naruszenia prawa do znaku ${ }^{135}$.

W orzeczeniu La Mer Technology v. Laboratoires Goemar ${ }^{136}$ ETS powtórzył, iż rzeczywistym użyciem znaku towarowego jest używanie go zgodnie $\mathrm{z}$ jego podstawową funkcją. Uściślił, że oce-

${ }^{131}$ Pkt. 65, 66 wyroku.

${ }^{132}$ Wyrok z dnia 23 października 2003 r. w sprawie Adidas-Salomon AG i Adidas Benelux BV przeciwko Fitnessworld Trading Ltd., nr C-408/01.

${ }^{133}$ Pkt. 27 wyroku.

${ }^{1.34}$ Pkt. 29 wyroku.

${ }^{135}$ Pkt. 41 wyroku.

1.36 Wyrok Sądu z dnia 27 stycznia 2004 r. w sparwie La Mer Technology Inc przeciwko Laboratoires Goemar S. A., nr C-259/02. 
niając, czy użycie znaku jest rzeczywiste należy zwrócić uwagę na wszystkie fakty i okoliczności, w szczególności, czy użycie to jest uzasadnione $\mathrm{w}$ określonej branży do utrzymania lub zdobycie udziału w rynku dla towarów lub usług opatrzonych znakiem, charakteru towarów lub usług, cech rynku zbytu i skali oraz częstotliwości użycia znaku. Jeśli w świetle powyższych okoliczności użycie znaku ma rzeczywisty handlowy cel, nawet minimalne użycie znaku lub użycie przez pojedynczego importera może być wystarczające dla uznania go za rzeczywiste w rozumieniu Dyrektywy ${ }^{137}$.

W wielowątkowym orzeczeniu Koninklijke KPN v. Benelux ${ }^{138}$ ETS powtórzył m.in. że art. 2 Dyrektywy odwzorowuje wypracowaną w orzecznictwie Sądu konstrukcję podstawowej funkcji znaku towarowego, która stanowi element konstytutywny znaku podlegającego ochronie na gruncie Dyrektywy ${ }^{139}$. Podobnie w orzeczeniu Henkel ${ }^{140}$ ETS podkreślił, że z faktu, iż znak towarowy ma pełnić swoją podstawową funkcję polegającą na gwarantowaniu źródła pochodzenia towaru lub usługi wynika, iż przeszkody rejestracji wymienione w art. 3 (1) Dyrektywy należy rozpatrywać zawsze w odniesieniu do towarów i usług, które mają zostać objęte ochroną ${ }^{141}$.

Orzeczenie Björnekulla v. Procordia ${ }^{142}$ dotyczyło unieważnienia znaku ze względu na utratę zdolności odróżniającej w wyniku przekształcenia w nazwę generyczną - art. 12 (2) (a) Dyrektywy ${ }^{143}$. In-

${ }^{137}$ Pkt. 27 wyroku.

${ }^{1.38}$ Wyrok Sądu z dnia 12 lutego 2004 r. w sprawie Koninkljke KPN Nederland NV przeciwsko Benelux-Markenbureau, nr C-363/99.

${ }^{139}$ Pkt. 80, 81 wyroku.

${ }^{1+11}$ Wyrok Sądu z dnia 12 lutego 2004 r. w sprawie Henkel KgaA, nr C-218/01.

${ }^{141}$ Pkt. 30, 31 wyroku.

142 Wyrok Sądu z dnia 29 kwietnia 2004 r. w sprawie Björnekulla Fruktindustrier AB przediwko Procordia Food AB, nr C-371/02.

${ }^{14.3}$ Art. 12 (2) (a): 2. Uprawnienie do znaku towarowego podlega również wygaśnięciu, jeżcli po dacic rejestracji: a) znak towarowy stał się w handlu, w wyniku działania lub zaniechania właściciela, nazwą powszechnie używaną w odniesieniu do towarów lub usług, dla których został zarejestrowany. 
terpretacji wymagało sformułowanie, że znak towarowy ma stać się nazwą powszechną w „handlu” (angl. 'in the trade'). Sąd krajowy pytal, opinie których odbiorców mają być decydujące: konsumentów lub odbiorców końcowych, czy podmiotów zajmujących się obrotem towarami na wcześniejszych etapach sprzedaży, w szczególności pośredników, czy też wszystkich odbiorców łącznie. ETS odwołując się do definicji podstawowej funkcji znaku towarowego i podkreślając, że obecnie znajduje ona swój wyraz w art. 2 Dyrektywy, stwierdził, że art. 12 (2) (a) Dyrektywy odwołuje się do sytuacji, w której znak towarowy nie jest w stanie dłużej spełniać swej funkcji. ETS stwierdził, że funkcja znaku towarowego jako oznaczenia pochodzenia ma decydujące znaczenie dla konsumentów lub odbiorców końcowych, niemniej jednak pełni też znaczące rolę dla pośredników zajmujących się profesjonalnie obrotem towarami. Tak jak w przypadku konsumentów i odbiorców końcowych wpływa na zachowanie pośredników na rynku ${ }^{144}$. Zdaniem ETS co do zasady to opinie konsumentów i odbiorców końcowych powinny być decydujące, niemniej jednak w zależności od specyfiki produktu, również odbiór pośredników powinien być wzięty pod uwagę $e^{145}$.

Orzeczenie Nichols ${ }^{146}$ dotyczyło rejestracji nazwiska jako znaku towarowego. Odwołując się do funkcji znaku towarowego wyrażonej w art. 2 Dyrektywy ETS stwierdził m.in., że do oceny zdolności odróżniającej znaku, którym jest nazwisko, stosuje się te same kryteria co w przypadku innych oznaczeń ${ }^{147}$.

W orzeczeniu Anheuser-Busch v. Budejovické Budvar ${ }^{148}$. ETS przypomniał m.in., iż celem prawa wyłącznego do znaku jest ochrona szczególnych interesów właściciela, tj. zagwarantowanie mu, iż znak

${ }^{1+4}$ Pkt. 23 wyroku.

${ }^{145}$ Pkt. 25 wyroku.

${ }^{146}$ Wyrok z dnia 16 września 2004 r. w sprawie Nichols plc przeciwko Registrar of trade Marks, nr C-404/02.

${ }^{147}$ Pkt. 25 wyroku.

${ }^{14 \times}$ Wyrok z dnia 16 listopada 2004 r. w sprawie Anheuser-Busch Inc przeciwko Budejovické Budvar, národní podnik, nr C-245/02. 
towarowy może wypełniać swoje funkcje. $\mathrm{Z}$ tego powodu wykonywanie prawa jest ograniczone do przypadków, kiedy użycie znaku przez osobę trzecią wpływa lub może wpływać na funkcje znaku towarowego, w szczególności na podstawową funkcję znaku towarowego polegającą na gwarantowaniu konsumentom pochodzenia towarów ${ }^{149}$.

W stanie faktycznym sprawy Gillette v. La-Laboratories ${ }^{150}$ podmiot niezwiązany z Gillette umieszczał na opakowaniu nożyków wymiennych do golarek opatrzonych znakiem producenta - Parason Flexor, naklejkę z informacją, iż nożyki pasują do uchwytów Parason Flexor i Gillette Sensor. Orzeczenie ETS dotyczyło art. 6 (1) (c) Dyrektywy ${ }^{151}$, tj. ograniczeń prawa do znaku towarowego ze względu na konieczność wskazania na zastosowanie produktu lub usługi. Na początku ETS przypomniał definicję podstawowej funkcji znaku towarowego ${ }^{152}$. Stwierdził także, iż celem art. 6 Dyrektywy jest pogodzenie podstawowych interesów związanych $\mathrm{z}$ ochroną znaków towarowych $\mathrm{z}$ zasadą swobodnego przepływu towarów i usług oraz wolnością świadczenia usług w taki sposób, aby znaki towarowe mogły pełnić swoją podstawową rolę w systemie niezakłóconej konkurencji ${ }^{153}$.

W dalszej części orzeczenia ETS nie odnosił się bezpośrednio do funkcji znaku towarowego, niemniej jednak w swym rozstrzygnię-

${ }^{140}$ Pkt. 59, podobnie pkt. 71.

${ }^{1511}$ Wyrok z dnia 17 marca 2005 r. w sprawie The Gillette Company i Gillette Group Finland Oy przeciwko LA - Laboratories Ltd Oy, nr C-228/03.

${ }^{15}$ Art. 6: Ograniczenie skutków znaku towarowego. 1. Znak towarowy nie upoważnia wlaściciela do zakazania stronie trzeciej używania w obrocie handlowym: a) jej własnego nazwiska lub adresu; b) wskazówek dotyczących rodzaju, jakości, ilości, zamierzonego przeznaczenia, wartości, pochodzenia geograficznego, daty produkcji towarów lub świadczenia usług, lub innych cech charakterystycznych towarów lub usług; c) znaku towarowego, jeżeli jest to niezbędne dla wskazania zamierzonego przeznaczenia towaru lub usługi, zwłaszcza akcesoriów lub części zamiennych; pod warunkiem że osoba ta używa ich zgodnie z uczciwymi praktykami w handlu i przemyśle. [...].

${ }_{152}^{15 k t .} 26$.

${ }^{153}$ Pkt. 29. 
ciu dotyczącym przesłanki „uczciwego użycia” oznaczenia, będącej jednym $\mathrm{z}$ warunków dozwolonego użycia znaku towarowego przez osobę nieuprawnioną, wymienił w sposób przykładowy okoliczności przemawiające za uznaniem danego zachowania za nieuczciwe. Użycie znaku towarowego ,nie będzie zgodne z uczciwymi praktykami w przemyśle i handlu, jeśli - na przykład: stwarza wrażenie, że pomiędzy osobą trzecią i właścicielem znaku jest powiązanie handlowe; jeśli wpływa na wartość znaku poprzez czerpanie nieuczciwych korzyści z jego odróżniającego charakteru lub renomy; prowadzi do dyskredytacji lub oczerniania znaku lub jeśli osoba trzecia przedstawia swój produkt jako imitację lub replikę produktu opatrzonego znakiem, który do niej nie należy ${ }^{154}$. Można zatem rozumieć, iż ETS odnosi 'nieuczciwe użycie' znaku do naruszenia funkcji znaku - odróżniającej - poprzez wywoływanie wrażenia powiązań między przedsiębiorstwami, tj., jak się wydaje - ryzyka konfuzji, oraz poprzez czerpanie nieuczciwych korzyści ze zdolności odróżniającej znaku; funkcji reklamowej poprzez niekorzystny wpływ na renomę znaku oraz gwarancyjnej - poprzez prezentowanie swojego produktu jako posiadającego te same właściwości, co produkt opatrzony znakiem. Jednocześnie ETS stwierdził, iż sam fakt użycia znaku towarowego $\mathrm{w}$ celu wskazania przeznaczenia produktu nie jest równoznaczny z przedstawieniem go jako posiadającego te same właściwości, w tym jakość, co produkt opatrzony znakiem.

Orzeczenie w sprawie Nestlé v. Mars ${ }^{155}$ dotyczyło uzyskania przez znak towarowy wtórnej zdolności odróżniającej w wyniku używania - art. 3 (3) Dyrektywy. ETS przypomniał, że użycie, które może prowadzić do nabycia zdolności odróżniającej ma mieć wyłącznie charakter użycia oznaczenia jako znaku towarowego ${ }^{156}$. Bez znaczenia jest jednak, czy oznaczenie było używane jako część zarejestrowanego znaku towarowego lub jako znak niezależny, uży-

${ }^{154}$ Pkt. 49.

${ }^{155}$ Wyrok Sądu z dnia 7 lipca 2005 r. w sprawie Société des produits Nestlé S.A. przeciwko Mars UK Ltd, nr C-353/03.

${ }^{156}$ Pkt. 26 wyroku. 
wany w zestawieniu ze znakiem zarejestrowanym. Istotne jest jedynie aby w konsekwencji takiego użycia stosowny krąg odbiorców postrzegał produkty lub usługi opatrzone wyłącznie tym znakiem, jako pochodzące $\mathrm{z}$ określonego przedsiębiorstwa ${ }^{157}$.

W orzeczeniu Praktiker ${ }^{158}$ ETS rozstrzygał, czy znak towarowy może być zarejestrowany dla usług polegających na detalicznej sprzedaży towarów, oraz na ile precyzyjnie ten rodzaj usług ma być określony, aby znak towarowy spełniał swoją podstawową funkcję, tj. odróżniał towary lub usługi pochodzące $z$ różnych przedsiębiorstw. ETS dopuścił rejestrację znaku dla tego rodzaju usług oraz stwierdził, że nie jest konieczne, aby przedstawiać ich specyfikę; wystarczy wskazać rodzaj lub typ towarów, których te usługi mają dotyczyćc ${ }^{159}$.

Orzeczenie Medion v. Thomson ${ }^{160}$ dotyczyło oceny ryzyka konfuzji - art. 5 (1) (b) Dyrektywy - pomiędzy wcześniejszym znakiem towarowym a znakiem późniejszym składającym się z nazwy właściciela znaku oraz znaku wcześniejszego należącego do osoby trzeciej, tj. 'LIFE' i 'THOMSON LIFE'. ETS uznał, że stwierdzenie istnienia ryzyka konfuzji nie może być uwarunkowane faktem, że ogólne wrażenie jest wywoływane przez tę część znaku złożonego z kilku elementów, która odpowiada znakowi wcześniejszemu ${ }^{161}$. W takiej sytuacji odebrana byłaby znakowi wcześniejszemu gwarantowana przez pkt. 10 Preambuły Dyrektywy jego ochrona jako oznaczenia pochodzenia towaru ${ }^{162}$. W konsekwencji ETS stwierdził, że w przypadku identycznych towarów lub usług ryzyko konfuzji może zaistnieć, jeśli znak jest złożony z nazwy spółki i wcześniejsze-

${ }^{157}$ Pkt. 30 wyroku.

${ }^{158}$ Wyrok Sądu z dnia 7 lipca 2005 r. w sprawie Praktiker Bau-und Heimwerkermärkte AG, nr C-418/02.

${ }^{159}$ Pkt. 52 wyroku.

${ }^{160}$ Wyrok Sądu z dnia 6 października 2005 r. w sprawie Medion AG przeciwko Thomson Multimedia Sales Germany \& Austria GmbH, nr C-120/04.

${ }^{161}$ Pkt. 22 wyroku.

${ }^{162}$ Pkt. 35 wyroku. 
go zarejestrowanego znaku towarowego należącego do innego podmiotu posiadającego normalną zdolność odróżniającą, przy czym jeśli ten drugi nie wplywa samodzielnie na ogólne wrażenie wywoływane przez znak towarowy, ale zachowuje w znaku złożonym swój niezależny odróżniający charakter. ${ }^{163}$

Sprawa Elizabeth v. Continental ${ }^{164}$ dotyczyła rejestracji znaku 'Elizabeth Emanuel' odpowiadającego imieniu i nazwisku pierwotnej projektantki i producentki towarów, która następnie zbyła swe przedsiębiorstwo i nie uczestniczyła w procesie produkcji i sprzedaży. ETS zajmował się przeszkodą rejestracji polegającą na wprowadzeniu odbiorców w błąd, np. co do natury, jakości, oznaczenia geograficznego towarów lub usług - art. 3 (1) (g) Dyrektywy ${ }^{165}$ oraz podstawą unieważnienia znaku ze względu na te same okoliczności - art. 12 (2) (b) Dyrektywy. ETS odniósł się do podstawowej funkcji znaku towarowego, wyrażonej w art. 2 Dyrektywy i powtórzył, że oznaczenie może być znakiem towarowym, jeżeli jest w stanie odróżniać towary lub usługi od pochodzących $\mathrm{z}$ innego przedsiębiorstwa ${ }^{166}$, oraz że aby pełnić swoją podstawową rolę w systemie niezakłóconej konkurencji znak towarowy musi stanowić gwarancję, że wszystkie towary lub usługi nim oznaczone zostały wyprodukowane lub dostarczone pod kontrolą jednego przedsiębiorstwa odpowiedzialnego za ich jakośćl ${ }^{167}$. ETS uznał, że mając powyższe na uwadze znak 'Elizabeth Emanuel' posiada zdolność odróżniania towarów lub usług. Uznał także, iż nawet je-

${ }^{16.3}$ Pkt. 37 wyroku.

${ }^{1 \omega}$ Wyrok Sądu z dnia 30 marca 2006 r. w sprawie Elizabeth Florence Emanuel przeciwsko Continental Shelf 128 Ltd, nr C-259/04.

${ }^{16.5}$ Art. 3: Podstawy odmowy lub stwierdzenia nieważności rejestracji. 1. Nie są rejestrowane, a za nieważne uznaje się już zarejestrowane: [...] g) znaki towarowe, które ze względu na swój charakter mogą wprowadzać w bląd opinię publiczną, na przyklad co do charakteru, jakości lub pochodzenia geograficznego towarów lub usługi.

${ }^{100}$ Pkt. 43 wyroku.

${ }^{167}$ Pkt. 44 wyroku. 
śli przeciętny konsument może kupować towary pod wplywem przekonania, że zostały one zaprojektowane przez projektantkę, której nazwiskiem są opatrzone, nie zmienia to faktu, że cechy i jakość ubioru gwarantowane są przez przedsiębiorstwo, które jest właścicielem znaku ${ }^{168}$. W konsekwencji stwierdził, iż z samej natury tego znaku nie wynika, aby zachodziła przesłanka wprowadzenia w błąd co do natury, jakości lub pochodzenia geograficznego towaru $^{169}$. Jak się wydaje można zatem uznać, że tym samym ETS podkreślit, iż znak towarowy w obecnym obrocie gospodarczo-prawnym pełni funkcję odróżniającą a nie funkcję pochodzenia towaru. Jest związany z przedsiębiorstwem - właścicielem znaku jedynie w sposób techniczny, nie niesie żadnego komunikatu dotyczącego swego źródła pochodzenia. Jest jedynie oznaczeniem odróżniającym towar od towarów tożsamych lub podobnych pochodzących $\mathrm{z}$ innych przedsiębiorstw.

\section{Podsumowanie}

Z zaprezentowanego przeglądu orzecznictwa wynika, że większość zagadnień prawa znaków towarowych wymaga odniesienia do funkcji pełnionych przez znak. Znaczenie kluczowe ma pojęcie 'podstawowej funkcji znaku towarowego' wypracowane w orzecznictwie ETS na wiele lat przed wejściem w życie Dyrektywy, a obecnie zawarte w art. 2.

Odróżnianie towarów pochodzących $\mathrm{z}$ różnych przedsiębiorstw stanowi tylko jedną z funkcji pełnionych przez znak towarowy, co wielokrotnie podkreślał ETS. Niemniej jednak w większości rozpatrywanych spraw ETS odnosi się wyłącznie do podstawowej funkcji znaku towarowego nie określając doniosłości i zakresu ochrony funkcji gwarancyjnej i reklamowej. Odwołanie do funkcji odróżniającej jest decydujące w kwestiach zdolności rejestrowej i unieważnienia praw do znaku. Można przyjąć, iż pełnienie tej

\footnotetext{
${ }^{106}$ Pkt. 48 wyroku.

${ }^{169}$ Pkt. 49 wyroku.
} 
funkcji przez oznaczenie, które ma podlegać rejestracji, bądź zostać unieważnione, jest kryterium wyłącznym przyznania lub odebrania mu ochrony.

W mojej ocenie, $\mathrm{z}$ dotychczasowego orzecznictwa ETS wynika, że naruszeniem praw do znaku na podstawie art. 5 (1) Dyrektywy jest wyłącznie oddziaływanie na funkcję odróżniającą ${ }^{170}$. Rozstrzygnięcia w sprawach dotyczących tego przepisu są jednak tak formulowane, iż możliwa jest zmiana stanowiska bez popadania w sprzeczność z wcześniejszymi orzeczeniami. W przypadku znaków lub towarów podobnych konieczne jest wykazanie prawdopodobieństwa wprowadzenia w błąd.

Funkcja reklamowa chroniona jest samodzielnie w przypadku znaków renomowanych, o ile ustawodawstwo krajowe taką ochronę przewiduje. Dodatkowo funkcja odróżniająca chroniona jest również w przypadkach tzw. rozwodnienia znaku bez konieczności zaistnienia wprowadzenia w błąd.

Wydaje się także, że ETS dopuszcza ochronę wszystkich funkcji znaku towarowego na podstawie art. 7 (2) Dyrektywy bez względu na fakt posiadania renomy przy zaistnieniu odpowiednich okoliczności. Przy czym ochrona funkcji odróżniającej może wyrażać się również w ochronie przed oddziaływaniem na zdolność odróżniającą oznaczenia.

W przypadku ograniczeń praw do znaku chroniona jest przede wszystkim funkcja odróżniająca poprzez zakaz wprowadzania klientów w błąd. Niemniej jednak ochronic mogą podlegać pośrednio także inne funkcje, jeśli określone zachowania używającego znaku można będzie uznać za nieuczciwe.

W wielu kwestiach związanych z ochroną poszczególnych funkcji znaku towarowego ETS nie przedstawił sprecyzowanych poglądów.

17" Odmiennie w literaturze polskiej K. SZcZEPANOwSKA-KoZtowsKa, Wyczerpanie praw wlasności przemyslowej. Patent i prawo ochronne na znak towarowy, Warszawa 2003, s. 79, w literaturze zagranicznej m.in. G. J. VıN DE K^мP, Protection of Trade Marks: The New Regime - Beyond Origin?, «E. I. P. R.» 1998 nr 10, s. 364-369. 
Wiele zagadnień nie było jeszcze przedmiotem pytań prawnych. Tematyka ta będzie $\mathrm{z}$ pewnością poddawana w przyszłości dalszej analizie. Coraz częściej podnosi się w literaturze, że ograniczenie ochrony znaków towarowych do ochrony funkcji odróżniającej nie odpowiada potrzebom współczesnego obrotu ${ }^{171}$. Wydaje się, iż nieliczne przypadki, w których ETS dopuszcza ochronę innych funkcji znaku towarowego nie mogą być uznane za wystarczające. Przepisy Dyrektywy są sformułowane na tyle ogólnie, iż nie determinują one zakresu ochrony przyznanego poszczególnym funkcjom. Wiele zależeć będzie zatem od przyszłego orzecznictwa ETS.

\section{FUNCTIONS OF A TRADEMARK ACCORDING TO THE JURISDICTION of THE EUROPEAN COURT OF JUSTICE}

\section{Summary}

The scope of protection of the functions fulfilled by trademarks determines most of the issues of the trademark law. The formulation of relevant provisions of the First Directive 89/104/EEC of the Council, of 21 December 1988, to Approximate the Laws of the Member States Relating to Trade Marks (,Directive") leave most of the issues open for interpretation. Therefore, it is the role of the European Court of Justice („ECJ") to define to what extent the origin, quality and advertising functions should be protected. The article presents in chronological order all ECJ's verdicts referring to the functions of a trademark issued both before and after entering into force of the Directive. The verdicts above all regard the issues of the trademark infringement, the distinguishing capability of a trademark, exhaustion and the limitations of the right to a trademark. It transpires from the review of the verdicts that ECJ refers most of the issues to the 'essential function of a trademark', which is

${ }^{17}$ Np. A. WAGnER, Infringing Trade Marks: Function, Association and Confusion of Signs According to the E. C. Trade Marks directive, «E. I. P. R.» $1999 \mathrm{nr} 3$, s. $127-132$. 
distinguishing goods originating form different enterprises, the concept worked out long before the Directive was introduced. As a result, it is still the origin function that is protected vast more broadly than other functions, which - as it seems - does not meet the needs of the contemporary turnover. Nevertheless, the formulation of most of ECJ's rulings is so general that it allows future modifications for the benefit of broadening the protection of the quality and advertising functions. 